NBER WORKING PAPER SERIES

\title{
LEVERAGE CONSTRAINTS AND THE INTERNATIONAL TRANSMISSION OF SHOCKS
}

Michael B. Devereux

James Yetman

Working Paper 16226

http://www.nber.org/papers/w16226

\author{
NATIONAL BUREAU OF ECONOMIC RESEARCH \\ 1050 Massachusetts Avenue \\ Cambridge, MA 02138 \\ July 2010
}

Devereux thanks the Federal Reserve Bank of Dallas for hospitality and support. Devereux also thanks the Bank for International Settlements, Bank of Canada, SSHRC and the Royal Bank of Canada for financial support. The views expressed here are those of the authors and do not necessarily reflect those of the Bank for International Settlements, the Bank of Canada, or the National Bureau of Economic Research. We thank, without implication, Phil Wooldridge for advice on data and seminar participants at the JMCB/Board of Governors Conference Financial Markets and Monetary Policy, June 4-5, 2009, and People's Bank of China - Bank for International Settlements Conference The International Financial Crisis and Policy Challenges in Asia and the Pacific, August 6-8, 2009, for comments, including in particular the discussants, Paolo Pesenti and Kyungsoo Kim. This paper was written while the first author was visiting the Reserve Bank of Australia and the Bank for International Settlements. He is grateful for the warm hospitality and resources provided by both institutions.

NBER working papers are circulated for discussion and comment purposes. They have not been peerreviewed or been subject to the review by the NBER Board of Directors that accompanies official NBER publications.

(C) 2010 by Michael B. Devereux and James Yetman. All rights reserved. Short sections of text, not to exceed two paragraphs, may be quoted without explicit permission provided that full credit, including (C) notice, is given to the source. 
Leverage Constraints and the International Transmission of Shocks

Michael B. Devereux and James Yetman

NBER Working Paper No. 16226

July 2010

JEL No. F2,F33,F34

\begin{abstract}
$\underline{\text { ABSTRACT }}$
Recent macroeconomic experience has drawn attention to the importance of interdependence among countries through financial markets and institutions, independently of traditional trade linkages. This paper develops a model of the international transmission of shocks due to interdependent portfolio holdings among leverage-constrained investors. In our model, without leverage constraints on investment, financial integration itself has no implication for international macro co-movements. When leverage constraints bind however, the presence of these constraints in combination with diversified portfolios introduces a powerful financial transmission channel which results in a positive co-movement of production, independently of the size of international trade linkages. In addition, the paper shows that, with binding leverage constraints, the type of financial integration is critical for international co-movement. If international financial markets allow for trade only in non-contingent bonds, but not equities, then the international co-movement of shocks is negative. Thus, with leverage constraints, moving from bond trade to equity trade reverses the sign of the international transmission of $\square$ Kocks.
\end{abstract}

Michael B. Devereux

Department of Economics

University of British Columbia

997-1873 East Mall

Vancouver, B.C.

CANADA V6T 121

and NBER

mbdevereux@gmail.com

James Yetman

Bank for International Settlements

Senior Economist

8 Finance Street, Central

Hong Kong SAR

james.yetman@bis.org 


\section{Introduction}

The recent international financial crisis has highlighted the critical role of financial markets in the propagation of business cycle shocks, both in transmitting shocks from one country to another and in magnifying the effects of those shocks. One key aspect of this transmission mechanism, seen in both the recent crisis as well as the Asian and Russian crises a decade ago, is the importance of balance sheet linkages among investors and financial institutions across countries. This implies that asset price collapses in one country are transmitted internationally through deteriorations in the balance sheets of institutions in countries holding portfolios of similar assets.

It is widely agreed that high financial leverage - a high ratio of assets to underlying capital - is a critical factor in the magnifying effects of financial crises. As asset values decline, highly levered financial institutions find their net worth sharply eroded and are forced to shed assets to avoid unacceptable risks of insolvency. But asset sales drive asset values down further, adversely impairing the balance sheets of other institutions. These institutions in turn are forced to sell assets, creating a vicious cycle of balance sheet deterioration and asset sales. While the financial dynamics of such balance sheet adjustments have been widely discussed elsewhere, it is less well understood how this process affects macroeconomic outcomes, or that this process alone may generate an immediate and powerful international transmission of shocks.

A clear pre-requisite for balance sheet adjustments to have powerful macroeconomic effects is the presence of financial frictions of some sort, or distortions in credit markets. After all, in a Modigliani-Miller world, leverage is irrelevant. Thus, in order to capture the dynamics of the financial meltdown, financial frictions will be of critical importance. 
In the context of the international transmission of business cycles, however, other puzzles arise. Most models of business cycle transmission still rely on international linkages due to trade flows. While global trade has been growing at remarkable rates over the past two decades, it is still the case that the major world regions - the United States, Asia and Europe - are to a large extent 'closed' economies, with the share of inter-regional trade representing only a small proportion of overall GDP. Thus Kose and Yi (2006) find that it is hard to account for the magnitude of business cycle co-movements among countries using conventional international real business cycle models. In addition there is evidence that business cycle co-movement is greater between countries with greater financial integration (Imbs 2004, 2006). Nevertheless, in the standard international business cycle model, enhanced international financial integration actually tends to reduce business cycle co-movement, since it allows for a more efficient reallocation of resources across countries in response to shocks (Heathcote and Perri 2002, 2005). But Krugman (2008) suggests that traditional multi-country business cycle models lack a critical 'international finance multiplier,' by which financial shocks in one country affect investment both in the original country and in other countries, through financial or balance sheet linkages.

This paper develops a theoretical model of a balance sheet channel for the international transmission of shocks. The model emphasizes how a process of balance sheet contractions, generated by a downturn in one country, is spread across countries through inter-connected portfolios. In the presence of leverage constraints, we show that this gives rise to a separate financial transmission mechanism of business cycle shocks that is independent of trade linkages. ${ }^{1}$

\footnotetext{
${ }^{1}$ In the recent literature, for example Krugman (2008), the adjustment of balance sheets is sometimes referred to as 'de-leveraging.' This term is inaccurate as a description of our model since, as in Kiyotaki and Moore (1997), the leverage ratio is constant. Nonetheless, the process of satisfying leverage constraints in the wake of asset price
} 
The paper's main contribution is to compare how macro shocks are transmitted under different financial market structures. We do not attempt to provide an integrated explanation of the recent crisis, or a full quantitative calibration, but instead highlight how the joint process of balance sheet constraints and portfolio interdependence generate an important cross-country propagation effect. We develop a two-country model in which investors borrow from savers, and invest in fixed assets. Investors also diversify their portfolios across countries and hold equity positions in the assets of the other country, as well as their own. Investors cannot commit to repay savers, however, and in order to ensure payment, may face limits on the maximum amount of leverage on their balance sheets.

We analyze four different variants of the model. First we consider a version of the model in which bond markets are segmented across countries but equity markets are integrated, both with and without binding leverage constraints. In the case where leverage limits do not bind there is no international transmission of shocks in final goods production. A negative productivity shock, which leads to a fall in the value of assets in one country, will cause investors to sell some assets and reduce their debt exposure, but this does not affect other countries. In fact investors in other countries increase their borrowing. More broadly, business cycle fluctuations in final goods production across countries are uncorrelated in the absence of limits on leverage.

When leverage constraints are binding, however, there is a powerful transmission of shocks across countries. A fall in asset values in one country forces a large and immediate process of balance sheet contractions for that country’s investors. But the fall in asset values leads to balance sheet deterioration in other countries that have internationally diversified asset portfolios, causing a sell-off in assets and a forced reduction in borrowing around the globe.

declines does impart a magnification effect on real activity. Endogenizing the maximum leverage ratio represents a separate issue, beyond the scope of this paper. For a recent contribution, see Geanakoplos (2009). 
This, in turn, drives a further sell-off in the first country, establishing a feedback loop. The end result is a large magnification of the initial shock, a large fall in investment, and highly correlated business cycles across countries during the resulting downturn.

We explore the relationship between financial integration and business cycle comovement further in a model with integrated bond markets. We assume that international bond markets are integrated across countries and leverage constraints always bind. We then contrast the properties of an economy without internationally diversified equity holdings with one with fully integrated equity markets. In the case where equity markets are segmented, we find that macroeconomic shocks are transmitted negatively across countries. A negative productivity shock in the home country pushes down investment there, but the resulting decline in world interest rates stimulates borrowing, investment and consumption in the foreign country. Hence borrowing, asset prices, output and consumption all move in opposite directions in the two countries.

The final variant of the model we explore is one where both bond and equity markets are integrated. Here we find positive co-movement across countries that is similar to a world without integrated bond markets.

The model has strong implications for understanding the effects of financial market integration. In the presence of leverage constraints and internationally diversified equity holdings, financial market integration (in equity markets) is associated with a 'financial contagion' effect, in the sense that asset price movements cause negative shocks to be propagated through balance sheets - propagation effects that would not occur in an international economy without international portfolio diversification. 
The contrasting results between the final two variants of the model also suggests that it may be important to distinguish the ex-ante from the ex-post gains to international portfolio diversification. In the absence of equity market integration, the presence of negative comovement in returns suggests substantial gains from portfolio diversification. But, in a world with binding leverage constraints, the process of integrating equity markets leads to strong positive co-movement in production, reducing the ex-post gains from diversification. ${ }^{2}$

The model draws heavily on a number of separate literatures. First, and most importantly, we follow Kiyotaki and Moore (1997) in imposing leverage constraints on investors. This leads to a wedge between the effective returns faced by investors and savers, and can act as an amplification mechanism for business cycle shocks. ${ }^{3}$ Second, we emphasize the linkages among countries through the presence of inter-connected portfolios. Portfolio linkages, in a somewhat different context, have for some time been seen as important in the contagion effects of financial shocks (see Rigobon 2003 and Pavlova and Rigobon 2008, for example). Finally, we introduce endogenous portfolio interdependence through the recently developed techniques of Devereux and Sutherland (2010a). ${ }^{4}$

The paper is organized as follows. The next section provides some evidence of the importance of a financial channel in the recent business cycle downturn. We then develop the basic two-country model in which investors and savers interact, but investors may be limited by

\footnotetext{
${ }^{2}$ It is important to distinguish co-movement in final goods production from that of asset prices and consumption. In almost any international macro model, greater financial market integration will give rise to positive co-movement in consumption and asset prices. But, in the standard international RBC model with frictionless asset markets, financial integration will tend to imply negative co-movement in production (and physical investment) - see, for example, Backus et al. (1992), Baxter and Crucini (1995) and Heathcote and Perri (2002, 2005). The contribution here is to show that leverage constraints, together with financial integration, tend to generate positive co-movement in final goods production.

${ }^{3}$ An alternative mechanism where balance sheets play a key role in business cycles is the 'financial accelerator' model of Bernanke et al. (1999). This has been extended to a multi-country setting by Gilchrist (2004).

${ }^{4}$ Dedola and Lombardo (2009) develop an interesting model similar to the present paper based on the financial accelerator model of Bernake et al. (2000), incorporating endogenous portfolios as in the present paper. They emphasise a somewhat different type of transmission effect, unique to the financial accelerator model, coming from the direct connection between risk-premia across countries.
} 
leverage constraints. In section 4 we explore the effects of a negative productivity shock in one country, and demonstrate the role of balance sheet adjustments in the propagation of business cycle shocks across countries. Section 5 then extends the model to allow for integrated bond markets, and section 6 considers the case of endogenous labor supply and investment. We then conclude.

\section{Empirical evidence}

We present some empirical evidence that supports our contention that balance sheet contractions may have been an important propagation mechanism for the current international crisis. First, Figure 1 documents the global nature of the economic crisis, demonstrating a remarkably synchronous collapse in economic growth rates for a sample of OECD countries. It is unlikely that trade linkages alone could account for the simultaneous downturns seen in all regions. If we take the US economy as the ultimate source of the financial crisis then it would be easy to explain the scale of the downturn in Mexico, for instance. But Figure 1 illustrates dramatic reductions in economic growth in many OECD economies, including some only marginally linked to the US through trade flows.

In addition there is clear evidence that US banks reduced their outstanding claims on the rest of the world. Table 1 contains short-term claims of US banks, for all OECD countries for which data is available. This is the total stock among US reporting banks of all claims on the destination economy with less than one year remaining until maturity. Under normal circumstances new claims are issued and many maturing existing claims are rolled over each quarter. A rapid decline in less than one year, then, implies little new issuance, and few existing exposures being rolled over. There is a clear pattern overall that the largest OECD economies (by size of claims) experienced a substantial fall in short-term US bank claims during 2008, 
including France, Germany, Ireland, Italy, Korea and Luxembourg. Further, total claims across all countries declined by more than 20 percent, with half of that decline occurring in the final quarter of 2008.

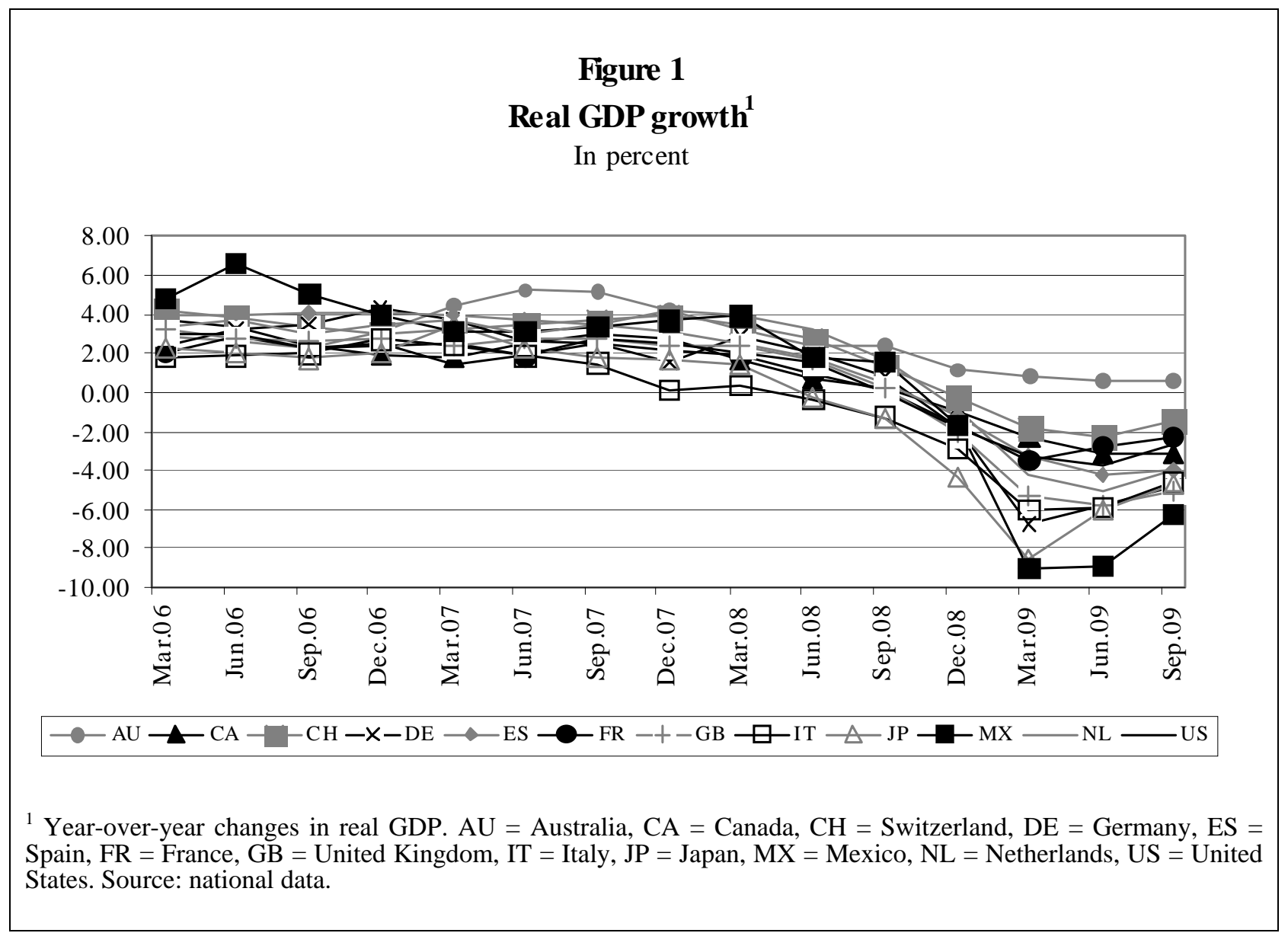

Aside from bank balance sheets, we can also find evidence consistent with balance sheet contractions in other instruments. Equities in particular were believed by some policymakers to be a vector of contagion, as the following quote by Rakesh Mohan, Deputy Governor of the Reserve Bank of India, indicated:

"Our problems are mainly due to the sell-off by foreign institutional investors in the domestic equity markets leading to a sharp reduction in net capital inflows and the sharp slowdown in global economic activity and external demand.” (Mohan 2009) 


\begin{tabular}{|c|c|c|c|c|c|}
\hline \multicolumn{6}{|c|}{$\begin{array}{c}\text { Table } 1 \\
\text { Short term claims of US banks on OECD economies } \\
\text { \$US millions }\end{array}$} \\
\hline Destination of Funds & 2007Q4 & 2008Q1 & 2008Q2 & 2008Q3 & 2008Q4 \\
\hline Austria & 4179 & 4207 & 4841 & 3537 & 2256 \\
\hline Belgium & 8742 & 13911 & 17453 & 15630 & 15567 \\
\hline Czech Republic & 527 & 716 & 798 & 894 & 518 \\
\hline Finland & 3191 & 2837 & 2386 & 3024 & 2928 \\
\hline France & 57952 & 69098 & 41790 & 43719 & 55287 \\
\hline Germany & 56910 & 65933 & 48407 & 40111 & 39266 \\
\hline Greece & 3947 & 4857 & 3005 & 2164 & 2428 \\
\hline Hungary & 894 & 1003 & 900 & 1113 & 491 \\
\hline Ireland & 28317 & 27471 & 28082 & 27357 & 23550 \\
\hline Italy & 25180 & 25521 & 26215 & 17012 & 17243 \\
\hline Korea & 26254 & 27435 & 28027 & 29873 & 21518 \\
\hline Luxembourg & 26050 & 24730 & 22826 & 21398 & 11943 \\
\hline Mexico & 6492 & 7752 & 7497 & 6574 & 7734 \\
\hline Netherlands & 43132 & 46995 & 52071 & 45699 & 37230 \\
\hline Poland & 2356 & 2254 & 2279 & 2308 & 2521 \\
\hline Portugal & 2861 & 2331 & 2054 & 1549 & 1226 \\
\hline Spain & 28267 & 28367 & 25370 & 15853 & 18420 \\
\hline Turkey & 7320 & 6916 & 7014 & 6009 & 5107 \\
\hline \multicolumn{6}{|c|}{ Source: BIS International Banking Statistics } \\
\hline
\end{tabular}

This view is consistent with the data on international capital flows captured by the Treasury International Capital System (Figure 2). The scale of the fall in both inflows and outflows starting in late 2008 is unprecedented over the full sample of aggregate TIC data going back to 1980. In our model we will see that the balance sheet contractions implied by this, when combined with binding leverage constraints among investors, can impart an independent international transmission of shocks. 
Figure 2

US capital inflows and outflows ${ }^{1}$

In billions of US dollars

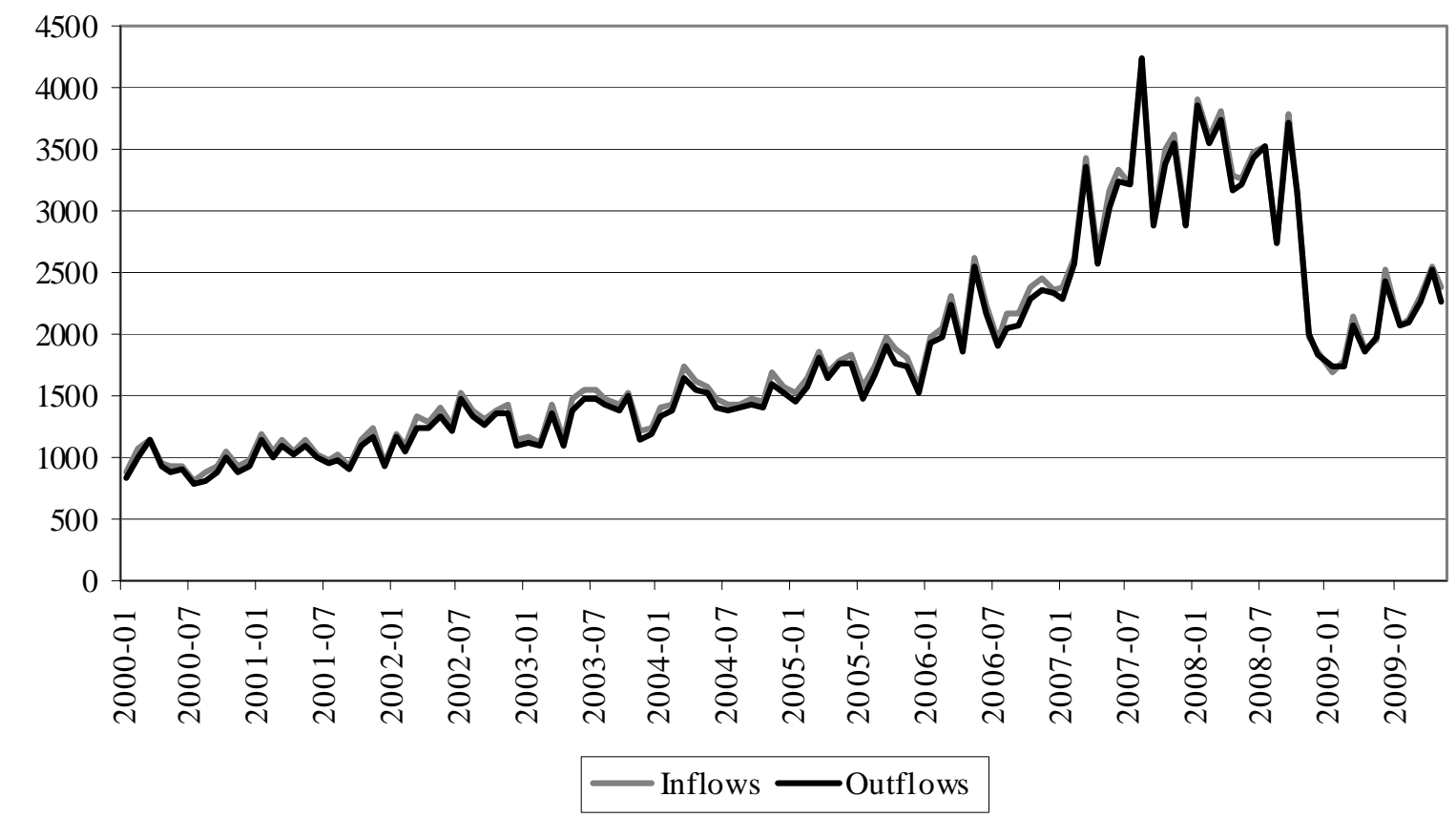

${ }^{1}$ Foreign purchases and sales of long-term domestic and foreign securities.

Source: US Department of the Treasury.

\section{Financial linkages versus trade linkages}

The effects of global balance sheet adjustments should be expected to vary by country. Some economies are more dependent on capital inflows than others, and countries with low credit ratings may suffer more from a sudden reduction in flows than higher rated countries, for example. Empirical evidence of the effects of a financial channel should reflect differences in vulnerabilities across countries.

We demonstrate the importance of balance sheet contractions as a propagation mechanism for the crisis using regression analysis. As a rough measure of the international effect 
of the crisis, we use the change in the growth rate of real GDP between the year ended December 2007 and December 2008. The vulnerability of countries to a sudden outflow of capital is calculated as total capital inflows from the US, as a percent of 2007 GDP, using US Treasury International Capital data (labeled TIC). Our sample includes all members of the OECD for which TIC data is available. We also include trade linkages, measured using exports to the US in 2007 as a percent of GDP $(X)$. Finally, we interact each of these variables with the sovereign credit rating of the economy $(C R)$, to capture the idea that capital withdrawals are likely to affect lower rated economies more heavily than higher rated ones, due to "flight to quality." Based on the Standard and Poor's sovereign foreign currency credit rating in December 2007, we convert the credit rating to a numerical scale where a value of 0 corresponds to a AAA-rating, 1 to a $\mathrm{AA}+$ rating, and so on, down to 12 for a BB- rating, the lowest in our sample.

The results are given in Table 2, and provide strong support for our argument that financial flows were a significant causal factor in the propagation of the crisis, while trade channels appear less important. First the export variables $(X$ and $C R X)$ are never economically or statistically significant, and sometimes enter with the wrong sign. Second our measure of capital flows (TIC) is statistically significant in all cases. Third, when we include an interactive term between the credit rating and the size of capital inflows from the US, the interactive term enters not only significantly, consistent with flight-to-quality, but the statistical support for TIC is also further strengthened. Finally, the adjusted $R$-squared statistics are supportive of capital inflows playing an important role in explaining the downturn, with trade channels being less important.

In summary, this evidence suggests that a financial channel may be important for the international propagation of shocks. Moreover, it is difficult to explain the scale and synchronicity of the global downturn based on trade alone. 


\begin{tabular}{|c|c|c|c|c|c|}
\hline \multicolumn{6}{|c|}{$\begin{array}{c}\text { Table } 2 \\
\text { Explaining the slowdown }\end{array}$} \\
\hline & (1) & (2) & (3) & (4) & (5) \\
\hline$X$ & $\begin{array}{r}-0.020 \\
(0.844)\end{array}$ & $\begin{array}{r}0.003 \\
(0.982)\end{array}$ & & & $\begin{array}{r}-0.043 \\
(0.662)\end{array}$ \\
\hline$C R X$ & & $\begin{array}{r}-0.007 \\
(0.775)\end{array}$ & & & $\begin{array}{r}0.039 \\
(0.144)\end{array}$ \\
\hline TIC & & & $\begin{array}{r}-0.005 \\
(0.035)\end{array}$ & $\begin{array}{r}-0.006 \\
(0.006)\end{array}$ & $\begin{array}{r}-0.007 \\
(0.005)\end{array}$ \\
\hline CRTIC & & & & $\begin{array}{r}-0.046 \\
(0.022)\end{array}$ & $\begin{array}{r}-0.078 \\
(0.009)\end{array}$ \\
\hline Adj. $\mathrm{R}^{2}$ & -0.036 & -0.072 & 0.133 & 0.278 & 0.294 \\
\hline Obs. & 29 & 29 & 27 & 27 & 27 \\
\hline \multicolumn{6}{|c|}{$\begin{array}{l}{ }^{1} \text { Dependent variable: real GDP growth rate in the year to } 2008 \mathrm{Q} 4 \text {, less the } \\
\text { growth rate in the previous year. } P \text {-values are in parentheses; bold indicates } \\
\text { significance at the } 5 \% \text { level. } X \text { equals exports to the US and TIC is gross } \\
\text { capital inflows from the US, each as a percentage of GDP, in } 2007 \text {. CRX } \\
\text { and } C R T I C \text { are interactive terms, where } C R \text { is the S\&P sovereign foreign } \\
\text { currency credit rating in } 2007 \text {. CR=0 corresponds to a AAA-rating, } 1 \text { for } \\
\text { AA+, and so on, to } 12 \text { for BB-. }\end{array}$} \\
\hline
\end{tabular}

\section{The model}

In this section we describe a basic two-country model with borrowers and lenders in each country. The countries are called home and foreign. Within each country there are investors and savers, both of whom use the same fixed asset and have infinite horizons. Investors purchase the fixed asset and rent it to production firms, receiving a risky return in exchange. We may think of this investment as the purchase of an equity claim in the production firm. Investors are more impatient than savers, so they will borrow from savers in order to invest in the fixed asset. ${ }^{5}$

\footnotetext{
${ }^{5}$ Because they are more impatient than savers, investors will never accumulate enough resources to cover the cost of investment in any period.
} 
Savers also make use of the fixed asset in home production. Savers therefore choose a portfolio in which they hold the debt of investors and the fixed asset. Savers do not hold domestic or foreign equity by assumption. We work with two versions of the model. In the first version savers lend only to domestic investors, so there is no cross country trade in non-contingent bonds. In the second version we allow for an open international bond market, so that investors may borrow from either domestic or foreign savers.

Investors face leverage constraints. They issue debt, but the maximum amount they can issue depends on their net worth. We will examine separately cases where these leverage constraints are binding and non-binding.

Whether or not leverage constraints bind, investors in either country may have the possibility of trading claims with investors in the other country so as to diversify their portfolio of equity holdings. Thus investors in each country finance their investment with debt, but may also have equity portfolios that are inter-connected across countries. Finally, both investors and savers in each country supply labor inelastically to production firms, and there is no physical capital accumulation. In section 6 we discuss how the model may be extended to accommodate endogenous capital accumulation and variable labor supply.

The focus of the analysis is to explore the joint process of leverage constraints and international portfolio integration in propagating macroeconomic shocks across countries.

\section{Investors}

We normalize the population of each country to unity, with a measure $n$ of investors and $1-n$ of savers. The representative investor in the home country maximizes:

$$
E_{t} \sum_{s=t}^{\infty} \theta_{s}^{I} U\left(C_{s}^{I}\right),
$$


where $C_{s}^{I}$ is consumption of the final good. To keep the analysis solely focused on financial inter-linkages between countries, it is assumed that there is just one world good. Adding an endogenous terms of trade to the analysis would enrich the response, but would not fundamentally alter the cross-country transmission of balance sheet adjustments modeled here, so long as the elasticity of substitution across home and foreign goods is not very close to unity. ${ }^{6}$

We define the discount factor for investors such that:

$$
\theta_{s+1}^{I}=\beta^{I}\left(\bar{C}_{s}^{I}\right) \theta_{s}^{I}
$$

with $\beta^{I}\left(\bar{C}_{s}^{I}\right) \leq 0$ where $\bar{C}_{s}^{I}$ is the economy-wide average consumption of investors. Thus the rate of time preference of investors is increasing in consumption, but is taken as given by each individual investor. The assumption of endogenous time preference for investors plays the usual role of ensuring a stationary wealth distribution among groups, both within and across countries. But it also plays a key role in allowing for a comparison of an economy in which leverage constraints bind with one where they do not bind, as we discuss below.

Investors receive income from their current holdings of domestic and foreign equity, and labor income from working in the domestic production firm. In addition, they must repay their debts owed to domestic savers. They then issue new debt, purchase equity claims on home and foreign investments and consume. The home country investor's budget constraint is written as:

$$
C_{t}^{I}+q_{1 t} k_{1 t}^{I}+q_{2 t} k_{2 t}^{I}=W_{t}^{I}+\left(q_{1 t}+R_{1 K t}\right) k_{1 t-1}^{I}+\left(q_{2 t}+R_{2 K t}\right) k_{2 t-1}^{I}+B_{t}^{I}-R_{t-1} B_{t-1}^{I},
$$

\footnotetext{
${ }^{6}$ As is well known, with an elasticity of substitution equal to unity, there is a high cross-country correlation of consumption purely due to the risk sharing implications of a terms-of-trade adjustment. This is seen, for instance, in the paper by Dedola and Lombardo (2009). Aghion et al. (2004) explore the importance of terms-of-trade movements in affecting borrowing constraints in an emerging market economy framework. Extending our model to a setting with an endogenous terms-of-trade would affect borrowing constraints through the impact of a terms-oftrade adjustment on net worth in a similar way to the effects of asset price changes in the present version of the model.
} 
where $q_{1 t}$ and $q_{2 t}$ represent the price of the fixed asset (or equity) in the home and foreign country respectively, and $k_{1 t}^{I}$ and $k_{2 t}^{I}$ are the portfolio holdings of the fixed assets in each country held by the home investor. The fixed asset of the home (foreign) country earns a dividend of $R_{1 K t}\left(R_{2 K t}\right)$. $W_{t}^{I}$ is wage income for the investor, who supplies one unit of labor. Finally, $B_{t}^{I}$ is the debt issued to domestic savers and $R_{t-1} B_{t-1}^{I}$ is payment on previously incurred debt.

One may question why only investors can purchase the fixed assets, which are then used by final goods firms. As in Bernanke et al. (1999), we could assume that investors (or, in their model, entrepreneurs) have some special capability for transforming a unit of the fixed asset into a usable factor of production that is rented to production firms. Savers cannot do this, and so may gain only indirectly from the investment, by lending to the investors. Savers can use the fixed asset only for use in home production, as described below.

In addition to constraint (2), investors face a constraint on total leverage due to an inability to commit to repayment, as in Kiyotaki and Moore (1997). Total debt is assumed to be restricted to be no greater than $\kappa$ times the market value of equity assets, where $\kappa<1$. Thus home investors’ choices are constrained by:

$$
B_{t}^{I} \leq \kappa\left(q_{1 t} k_{1 t}^{I}+q_{2 t} k_{2 t}^{I}\right)
$$

The full leverage rate (the value of assets to capital) for investors is then $1 /(1-\kappa)$ in the case where the leverage constraint (3) is binding. Leverage constraints in the form of (3) have been used quite widely in the literature on asset prices (Aiyagari and Gertler 1999), emerging market crises (Mendoza and Smith 2006), borrowing in a small open economy (Uribe 2006) and monetary policy with credit frictions in housing markets (Iacoviello, 2005). Kiyotaki and Moore 
(1997) show that $\kappa$ may depend on the borrowing rate and expected capital gains on equity under some circumstances. We assume that $\kappa$ is a fixed parameter in our analysis.

Investors in the home country choose a portfolio based on investments in the home equity and the foreign equity, as well as their total borrowing and consumption, to maximize their expected utility subject to their budget constraint (2) and leverage constraint (3), giving the conditions:

$$
\begin{aligned}
& U^{\prime}\left(C_{t}^{I}\right)=E_{t} \beta^{I}\left(C_{t}^{I}\right) U^{\prime}\left(C_{t+1}^{I}\right) \frac{\left(q_{1 t+1}+R_{1 K t+1}\right)}{q_{1 t}}+\kappa \mu_{t}, \\
& U^{\prime}\left(C_{t}^{I}\right)=E_{t} \beta^{I}\left(C_{t}^{I}\right) U^{\prime}\left(C_{t+1}^{I}\right) \frac{\left(q_{2 t+1}+R_{2 K t+1}\right)}{q_{2 t}}+\kappa \mu_{t}, \\
& U^{\prime}\left(C_{t}^{I}\right)=E_{t} \beta^{I}\left(C_{t}^{I}\right) U^{\prime}\left(C_{t+1}^{I}\right) R_{t}+\mu_{t},
\end{aligned}
$$

where $\mu$ is the multiplier on the leverage constraint. This may be interpreted as the shadow price (or marginal utility) of an extra unit of debt to the investor. If this is positive, it means that the investor would like to borrow more, but is constrained by (3). Thus $\mu$ is a measure of the value of the opportunity to make a levered investment. To show this, put (4), (5) and (6) together to obtain:

$$
\mu_{t}=E_{t} \beta^{I}\left(C_{t}^{I}\right) U^{\prime}\left(C_{t+1}^{I}\right)\left[\frac{\omega_{t} r_{1, t+1}+\left(1-\omega_{t}\right) r_{2, t+1}-R_{t}}{1-\kappa}\right],
$$

where $\omega_{t}=q_{1, t} k_{1, t} /\left(q_{1, t} k_{1, t}+q_{2, t} k_{2, t}\right)$ is the share in home equity, $r_{1, t+1}=\left(q_{1, t+1}+R_{1 K, t+1}\right) / q_{1, t}$ is the return on the home equity and $r_{2, t+1}=\left(q_{2, t+1}+R_{2 K, t+1}\right) / q_{2, t}$ is the return on the foreign equity. Equation (7) shows that, when $\mu>0$, the expected return on the portfolio, up to the first-order, exceeds the cost of borrowing. 
Note that the leverage constraint does not directly affect the investors' incentive to diversify equity across countries, since (3) applies equally to borrowing for domestic or foreign equity purchases. Thus we may put (4) and (5) together to get the standard portfolio selection condition:

$$
E_{t} U^{\prime}\left(C_{t+1}^{I}\right)\left(\frac{\left(q_{1 t+1}+R_{1 K t+1}\right)}{q_{1 t}}-\frac{\left(q_{2 t+1}+R_{2 K t+1}\right)}{q_{2 t}}\right)=0 .
$$

Given that the portfolio choice may be written in the form (8), we can derive the optimal equity portfolio of each country's investors following Devereux and Sutherland (2010a). We discuss the details involved in portfolio choice more fully below.

\section{Savers}

Savers have preferences given by:

$$
E_{t} \sum_{s=t}^{\infty} \theta_{s}^{S} U\left(C_{s}^{S}\right) .
$$

As for investors, we define the discount factor such that $\theta_{s+1}^{S}=\beta^{S}\left(\bar{C}_{s}^{S}\right) \theta_{s}^{S}$, with $\beta^{S}\left(\bar{C}_{s}^{I}\right) \leq 0$, where $\bar{C}_{s}^{I}$ is the economy-wide aggregate consumption of savers. Assume that savers are inherently more 'patient' than investors, so that:

$$
\beta^{S}(x)>\beta^{I}(x),
$$

for all feasible values of $x$. Assumption (10) ensures that savers will lend to investors, even in a steady state where the leverage constraint (3) is not binding. ${ }^{7}$

Savers purchase the fixed asset, and buy debt from investors. They receive wage income from working in the final goods sector, and returns on their lending to investors. In addition they

\footnotetext{
${ }^{7}$ An alternative, but considerably more difficult, approach to achieving an equilibrium with levered investment is to assume that investors are less risk averse than savers. Solving a model with leverage based on risk preferences would necessitate using a higher order of approximation to the full stochastic model.
} 
have a residual 'home production function' that uses the fixed asset. ${ }^{8}$ An individual saver owning $k_{1, t}^{S}$ of the fixed asset produces $G\left(k_{1, t}^{S}\right)$ in terms of home production, where $G^{\prime}\left(k_{1, t}^{S}\right)<0$. For simplicity, we assume that home production is perfectly substitutable with the final good in savers' utility. ${ }^{9}$ With this assumption, we may write the saver's budget constraint as:

$$
C_{t}^{S}+q_{1 t} k_{1 t}^{S}=W_{t}^{S}+q_{1 t} k_{1 t-1}^{S}+G\left(k_{1 t-1}^{S}\right)+B_{t}^{S}-R_{t-1} B_{t-1}^{S} .
$$

Note that, by assumption, savers purchase only the domestic fixed asset. They do not have access to the same investment opportunities as investors and therefore only have use for the domestic fixed asset, as it may be utilized in home production. On the other hand, savers' purchases of debt from investors are unconstrained.

The first-order conditions for the optimal choice of $k_{1 t}^{S}$ and $B_{t}^{S}$ are simply:

$$
\begin{aligned}
& U^{\prime}\left(C_{t}^{S}\right)=E_{t} \beta^{S}\left(C_{t}^{S}\right) U^{\prime}\left(C_{t+1}^{S}\right) \frac{\left(q_{1 t+1}+G^{\prime}\left(k_{1, t}^{S}\right)\right)}{q_{1 t}}, \\
& U^{\prime}\left(C_{t}^{S}\right)=E_{t} \beta^{S}\left(C_{t}^{S}\right) U^{\prime}\left(C_{t+1}^{S}\right) R_{t} .
\end{aligned}
$$

\section{Production firms}

Production firms in each country hire labor and fixed assets in order to produce. Firms are competitive, and maximize profits given the production function:

$$
Y_{t}=A_{t} F\left(L_{t}, K_{t-1}\right) \text {, }
$$

\footnotetext{
${ }^{8}$ As in Kiyotaki and Moore (1997), we think of this fixed asset as being more productive when used to produce final goods, and having a residual usage in home production for savers. According to this interpretation, savers do not receive dividend income on the use of the fixed asset in home production, since this is paid only on the 'transformed' asset after its purchase by investors.

${ }^{9}$ Specifically, we define savers' consumption as $C_{t}^{s}=\hat{C}_{t}^{s}+G\left(k_{1 t-1}^{s}\right)$, where $\hat{C}_{t}^{s}$ is savers' consumption of the final good, and $G\left(k_{1 t-1}^{S}\right)$ is savers' home production.
} 
where $L_{t}$ is effective employment and $K_{t-1}=n\left(k_{1, t-1}^{I}+k_{1, t-1}^{* I}\right)$ is the firm's fixed assets. Profit maximization then implies that:

$$
\begin{aligned}
& W_{t}=A_{t} F_{1}\left(L_{t}, K_{t-1}\right), \\
& R_{1 K, t}=A_{t} F_{2}\left(L_{t}, K_{t-1}\right) .
\end{aligned}
$$

\section{Equilibrium}

Equilibrium of the two-country world economy entails market clearing for the world market of the fixed asset, as well as equilibrium in the debt market. First take the case where national debt markets are segmented, so that domestic investors borrow from domestic savers only. Then, for the home economy, it must be the case that:

$$
n B_{t}^{I}+(1-n) B_{t}^{S}=0
$$

In the case where there is a common world bond market, (17) is replaced by

$$
n\left(B_{t}^{I}+B_{t}^{I^{*}}\right)+(1-n)\left(B_{t}^{S}+B_{t}^{S^{*}}\right)=0 .
$$

For the home economy, equilibrium in the market for the fixed asset is defined as:

$$
n k_{1, t}^{I}+n k_{1, t}^{* I}+(1-n) k_{1, t}^{S}=1 \text {, }
$$

where $k_{1, t}^{* I}$ represents foreign country investors' real holdings of the home asset at the beginning of time $t+1$. In addition, the world market clearing condition must be satisfied:

$$
\begin{aligned}
& n\left(C_{t}^{I}+C_{t}^{* I}\right)+(1-n)\left(C_{t}^{S}+C_{t}^{* S}\right)=A_{t} F\left(1, n\left(k_{1, t-1}^{I}+k_{1, t-1}^{* I}\right)\right) \\
& +A_{t}^{*} F\left(1, n\left(k_{2, t-1}^{I}+k_{2, t-1}^{* I}\right)\right)+(1-n)\left(G\left(k_{1, t-1}^{S}\right)+G\left(k_{2, t-1}^{* S}\right)\right) .
\end{aligned}
$$

This condition incorporates the fact that the total labor supply of investors and savers sums to unity, and total use of the fixed factor by final goods firms is equal to total holdings by domestic and foreign investors. 
We solve for four variants of the model and, in the process, conduct two experiments. We first assume that bond markets are segmented across countries, but equity markets are integrated internationally. We then solve separately for an equilibrium where the leverage constraint is slack and when the leverage constraint is binding. ${ }^{10}$ Next we assume that international bond markets are integrated across countries, so that there is one world interest rate on bonds and, in addition, leverage constraints always bind. In this environment we contrast the properties of the economy where equity markets are separated (no cross holdings of equity) with an environment of full integration of equity markets (full portfolio diversification).

The first experiment allows us to explore the effects of leverage constraints in a global economy where equity markets are integrated (although, as discussed below, we vary the degree of diversification in this case). The second experiment allows us to explore the implications of different forms of financial market integration in a global economy where leverage constraints are binding in each country.

The equilibrium conditions may be characterized as follows. First, for the model with segmented national bond markets, integrated equity markets and slack leverage constraints, the full equilibrium is described by equations (2), (4)-(6), (11)-(13), (15)-(17) and (18) for both the home and foreign country, and the world market clearing condition (19). This gives 23 equations in the 22 variables $C_{t}^{I}, C_{t}^{S}, C_{t}^{* I}, C_{t}^{* S}, k_{1, t}^{I}, k_{2, t}^{I}, k_{1, t}^{S}, k_{1, t}^{* I}, k_{2, t}^{* I}, k_{2, t}^{* S}, B_{t}^{I}, B_{t}^{S}, B_{t}^{* I}, B_{t}^{* S}, q_{1, t}, q_{2, t}$, $R_{t}, R_{t}^{*}, W_{t}, W_{t}^{*}, R_{1 K, t}$ and $R_{2 K, t}$, with one equation redundant by Walras' law (note that in this case, because leverage constraints never bind, we have $\left.\mu_{t}=\mu_{t}^{*}=0\right)$. In the case where leverage constraints always bind, the full equilibrium is described by equations (2)-(6), (11)-(13), (15)-

\footnotetext{
${ }^{10}$ The solution approach we use does not allow us to accommodate an outcome with 'occasionally binding' leverage constraints.
} 
(17) and (18) for both the home and foreign country, and the world market clearing condition (19). This gives 25 equations in the 24 variables $C_{t}^{I}, C_{t}^{S}, C_{t}^{* I}, C_{t}^{* S}, k_{1, t}^{I}, k_{2, t}^{I}, k_{1, t}^{S}, k_{1, t}^{* I}, k_{2, t}^{* I}$, $k_{2, t}^{* S}, B_{t}^{I}, B_{t}^{S}, B_{t}^{* I}, B_{t}^{* S}, q_{1, t}, q_{2, t}, R_{t}, R_{t}^{*}, \mu_{t}, \mu_{t}^{*}, W_{t}, W_{t}^{*}, R_{1 K, t}$ and $R_{2 K, t}$, with one equation redundant by Walras’ law.

In the case with a common world bond market, leverage constraints and segmented international equity markets, we have conditions (2)-(4), (6), (11)-(13), (15)-(16) and (18) for the home country, and analogous expressions for the foreign country, while condition (17) for each country is replaced by the single condition (17’) which, in conjunction with (19), gives us 22 equations in 21 variables $C_{t}^{I}, C_{t}^{S}, C_{t}^{* I}, C_{t}^{* S}, k_{1, t}^{I}, k_{1, t}^{S}, k_{2, t}^{* I}, k_{2, t}^{* S}, B_{t}^{I}, B_{t}^{S}, B_{t}^{* I}, B_{t}^{* S}, q_{1, t}, q_{2, t}$, $R_{t}, \mu_{t}, \mu_{t}^{*}, W_{t}, W_{t}^{*}, R_{1 K, t}$ and $R_{2 K, t} \cdot{ }^{11}$ Finally, in the case with a common world bond market, leverage constraints and integrated world equity markets, we add condition (5) to the previous list for the home country, along with its analogue for the foreign country, and we now solve for two additional variables, $k_{2, t}^{I}$ and $k_{1, t}^{* I}$.

Although this fully describes the set of equilibrium conditions and endogenous variables for each version of the model, the solution method involves taking a linear approximation around a non-stochastic steady state version of each model. In this case, a well-known difficulty arises due to the problem of determining the portfolio holdings of investors in a non-stochastic steady state. In particular, if equity markets are integrated and both assets are to be held by investors, equilibrium must be characterized by indifference among investors, at the margin, between holdings of home and foreign equities. This implies that, in a non-stochastic steady state, the assets must command identical returns, and there is no unique optimal portfolio share for an

\footnotetext{
${ }^{11}$ Note that in this case there are no international cross-holdings of equity.
} 
investor. But using the method of Devereux and Sutherland (2010a), the characteristics of the equilibrium portfolio may be approximated. The method allows for a derivation of the zero-order (or steady state) component of the equilibrium portfolio using a second order approximation of the portfolio selection equation, in conjunction with a first order approximation of the remaining parts of the model. This approximation gives us the degree to which investors in each country will choose to be exposed to equity markets in the other country, and allows an analysis of the stochastic equilibrium of the first-order approximation to the model with integrated world equity markets. ${ }^{12}$

It is important to emphasize that this indeterminacy of portfolio shares up to a first order approximation applies only to the choice of home and foreign equity conditional on the allocation of the fixed asset between the final goods sector and the home production sector in each country. This allocation itself, giving the total supply of equity, denoted by $\hat{k}_{1, t}^{I}=k_{1, t}^{I}+k_{1, t}^{* I}$ for the home economy and $\hat{k}_{2, t}^{I}=k_{2, t}^{I}+k_{2, t}^{* I}$ for the foreign economy, is clearly determinate in a non-stochastic steady state, as evidenced by equations (19) (for the case without leverage constraints) or (20) (for the case with leverage constraints). Thus, the total supply of equity is determinate in a steady state, but the ownership pattern must be obtained using higher order approximations. In the impulse responses discussed below, we report the dynamics of total equity, which can be obtained from a simple linear approximation, rather than the dynamics of the investors' equity portfolios (which would require a second order approximation to the model as described in Devereux and Sutherland (2010b)).

\section{Properties of the steady state}

\footnotetext{
${ }^{12}$ This aspect of the solution method is described in more detail in an appendix available from the authors.
} 
Before examining the dynamics of balance sheet adjustments within the model, we first discuss some properties of the non-stochastic steady state. Since the model is symmetric and there is a stationary wealth distribution, the steady state is identical in the two types of bond market arrangements.

When leverage constraints do not bind, it follows from a combination of (4) and (6), together with (12), (13) and (16), that the fixed asset is allocated efficiently between the final good sector and home production. That is, for the home economy, we have:

$$
G^{\prime}\left(k_{1}^{S}\right)=A F_{2}\left(1, n \hat{k}_{1}^{I}\right),
$$

Where $n \hat{k}_{1}^{I}$ represents the total quantity of the fixed asset used in the final goods production sector and $\hat{k}_{1}^{I}=k_{1}^{I}+k_{1}^{* I}$. Thus the marginal product of the fixed asset is equalized between home production and final goods production.

In combination with the resource constraint $n \hat{k}_{1}^{I}+(1-n) k_{1}^{S}=1$, this uniquely determines the allocation of assets in final goods production. Therefore there is no interdependence across countries in asset allocation in steady state when leverage constraints do not bind. In fact, we can extend this result further. In the case where leverage constraints never bind it is easy to see that there is no interaction between asset allocations across countries at all, at least up to a first-order approximation. This can be seen by taking a linear approximation of (4), (6), (12), (13) and (16) to obtain the condition:

$$
\gamma_{1} \frac{d k_{1, t+1}^{S}}{k_{1}^{S}}=E_{t} \frac{d A_{t+1}}{A}+\gamma_{2} \frac{d \hat{k}_{1, t+1}^{I}}{\hat{k}_{1}^{I}},
$$

where $\gamma_{1}$ and $\gamma_{2}$ are constant coefficients. Hence the dynamic paths of asset allocations are independent across countries, despite the fact that, up to a first-order, expected returns on all assets are equalized both within and across countries. 
A more general feature of this environment is that the degree of financial integration does not affect the allocation of real assets. That is, allocation of the fixed asset between home production and investment in the final good is independent of the ownership of equities. This property does not hold in an economy with binding leverage constraints. ${ }^{13}$

When leverage constraints bind, we again use (4), (6), (12), (13) and (16) to obtain the steady state condition:

$$
G^{\prime}\left(k_{1}^{S}\right)=\frac{\beta^{I}\left(1-\beta^{S}\right)}{\beta^{S}\left(1-\beta^{I}\right)-\kappa\left(\beta^{S}-\beta^{I}\right)} A F_{2}\left(L, n \hat{k}_{1}^{I}\right) .
$$

From condition (3) it must be true that $\beta^{I}\left(1-\beta^{S}\right) /\left[\beta^{S}\left(1-\beta^{I}\right)-\kappa\left(\beta^{S}-\beta^{I}\right)\right]<1$. It follows that, under binding leverage constraints, the final goods sector has an inefficiently low level of the fixed asset. More generally, however, since discount factors are endogenous, the allocation of fixed assets across sectors will no longer be independent across countries. With free trade in equities across countries, returns to investors must be equal in both countries. Since returns interact with movements in consumption through the endogenous rate of time preference, (21) shows that the division of resources between home production and final goods must be linked across countries as well. Even in the case of constant time preference, however, the presence of leverage constraints would still imply a dynamic interaction between output levels across countries, because productivity shocks to one country will affect the tightness of leverage constraints across all financial markets. We explore this in detail below.

\section{Portfolio choice}

\footnotetext{
${ }^{13}$ In a more general model with endogenous capital accumulation and variable labor supply, the degree of financial integration will affect business cycle correlations across countries. As discussed in the introduction, however, financial integration generally reduces the co-movement of business cycles across countries in the standard model (Heathcote and Perri 2004). The main point here is to show that the presence of balance sheet constraints introduces substantial forces for positive cross-country correlations that would otherwise be absent. In section 6 below, we discuss how the results extend to a model with capital accumulation and endogenous labor supply.
} 
Equations (20) or (21) determine the steady state allocation of the fixed asset in final goods production, with non-binding or binding leverage constraints respectively. This determines the total supply of equity in each country. But the share of each country's equity held by home and foreign investors (the portfolio shares $k_{1}^{I}$ and $k_{1}^{* I}$ ) must also be determined. Clearly, in order to analyze the dynamic response to productivity shocks in one country, it is necessary to understand the pattern of equity holdings of investors in each country. To do this we follow Devereux and Sutherland (2010a) in using a second-order expansion of (8) to obtain an approximation of optimal portfolio holdings. ${ }^{14}$

In practice it is convenient to rewrite the model to determine the net international equity position of each country. Since only investors have access to equity markets by assumption, it is sufficient to look at the portfolio decisions of home and foreign investors. First take the budget constraint for home country investors (2). This may be rewritten as:

$$
C_{t}^{I}+N F A_{t}=W_{t}^{I}+R_{1 K t} \hat{k}_{1 t-1}^{I}-q_{1 t}\left(\hat{k}_{1 t}^{I}-\hat{k}_{1 t-1}^{I}\right)+r_{2 t} N F A_{t-1}+r_{x t}\left[q_{1 t-1}\left(k_{1 t-1}^{I}-\hat{k}_{1 t-1}^{I}\right)\right]+B_{t}^{I}-R_{t-1} B_{t-1}^{I},
$$

where NFA denotes net foreign assets, defined as $N F A_{t}=q_{2 t} k_{2 t}^{I}-q_{1 t}\left(\hat{k}_{1 t}^{I}-k_{1 t}^{I}\right)$, which is the excess of the home investors' holdings of foreign equity relative to foreign investors' holdings of domestic equity. In addition, $r_{x t}$ is the ex-post excess return on the portfolio:

$$
r_{x t}=r_{1 t}-r_{2 t} \equiv\left(\frac{q_{1 t}+R_{1 K, t}}{q_{1 t-1}}\right)-\left(\frac{q_{2 t}+R_{2 K, t}}{q_{2 t-1}}\right)
$$

For given NFA, the portfolio choice may be described as the choice of $\alpha_{t}=q_{1 t-1}\left(k_{1 t-1}^{I}-\hat{k}_{1 t-1}^{I}\right)$, which is the net holding of home country equity by home agents. If $\alpha_{t}<0$, the investors diversify in the sense that less than 100 percent of all home equity is owned by home investors.

${ }^{14}$ A detailed description of the solution approach is contained in an appendix available from the authors. 
Given $N F A_{t}$, home investors' holdings of foreign equity are equal to $N F A_{t}-\alpha_{t}$ and equation (22)

is the only part of the model where the portfolio term $\alpha_{t}$ enters. But it is still necessary to obtain

a solution for $\alpha_{t}$ in order to characterize how equity markets affect international transmission.

Devereux and Sutherland (2010a) show that, when the properties of the model are analyzed up to a first-order approximation, $\alpha_{t}$ is a constant and is determined by a combination of a secondorder approximation of (8), together with a first-order approximation of the rest of the model. ${ }^{15}$

In the solution below, following Tille and van Wincoop (2007), we extend (8) to allow for transactions costs of international financial trade that effectively limit international portfolio diversification. This represents a brute-force technique for generating home equity bias. In particular, we assume that an 'iceberg' cost factor given by $\exp (-\tau) \leq 1$ reduces the returns that home investors receive from foreign investment so that condition (8) becomes:

$$
E_{t} U^{\prime}\left(C_{t+1}^{I}\right)\left(\frac{\left(q_{1 t+1}+R_{1 K t+1}\right)}{q_{1 t}}-\frac{\left(q_{2 t+1}+R_{2 K t+1}\right)}{q_{2 t}} \exp (-\tau)\right)=0 \text {. }
$$

In addition, we follow Tille and Van Wincoop in assuming that $\tau$ is a small, second-order term. This means that while it does affect the solution for the equilibrium portfolio, which is evaluated using a second-order approximation of (8'), it does not impact on the first-order dynamics of the model, except insofar as it affects the choice of the portfolio itself.

Note that given the definition of net foreign assets, the leverage constraint for home country investors may be written:

$$
B_{t} \leq \kappa\left(N F A_{t}+q_{1 t} \hat{k}_{1 t}^{I}\right)
$$

\footnotetext{
${ }^{15}$ Note that the constant approximation for $\alpha_{t}$ is the only aspect of the portfolio solution that is explicitly incorporated in the model. Given this approximation, all other aspects of the model can be analyzed using a first order approximation, including the dynamics of total equity (the part of the fixed asset invested in final goods production). As emphasized above, in order to compute the dynamics of the ownership of equity (the dynamics of $\alpha_{t}$ ), it would be necessary to solve the model using a higher order of approximation.
} 
Thus, holding home asset prices constant, an increase in net foreign assets generated by either a current account surplus or a capital gain on the external portfolio (i.e. valuation effects) will loosen the leverage constraint. But since $N F A_{t}+N F A_{t}^{*}=0$, this will simultaneously tighten the leverage constraint facing foreign investors. Therefore the degree to which leverage linkages govern the transmission of shocks across countries depends on the dynamics of net foreign assets, and these in turn are linked to the portfolio choices made by home and foreign investors.

\section{Calibration}

Because this version of the model is such a stripped-down representation of a full-scale DSGE framework, lacking capital accumulation and dynamics in labor supply and containing only a single world good, there are many dimensions in which the model's predictions will depart from reality. The aim of the exercise is solely to explore the way in which the interaction of leverage constraints and portfolio interdependence affect the cross-country dynamics of asset prices, asset allocations and levered investments. To do this, however, we need to choose parameter values for preferences, production technologies and the leverage constraint itself. Table 3 gives the set of parameter values used in the baseline model.

\begin{tabular}{|l|l|l|l|l|l|}
\hline \multicolumn{2}{|c|}{$\begin{array}{c}\text { Table 3 } \\
\text { Calibration }\end{array}$} & Value \\
\hline$n$ & Proportion of investors & 0.5 & $\varepsilon$ & Capital share in final goods production & 0.36 \\
\hline$\eta$ & Discount function & 0.022 & $\omega$ & Capital share in home production & 0.1 \\
\hline$\zeta$ & Discount function & See text & $\sigma$ & Coefficient of relative risk aversion & 2 \\
\hline$\kappa$ & Leverage & $0.5,0.75$ & $\rho$ & Productivity shock persistence & 0.9 \\
\hline
\end{tabular}


We assume that the measure of investors and savers is equal, so that $n=0.5$. In the leverage constrained economy, this accords with the estimates of Campbell and Mankiw (1990) regarding the share of households that are subject to credit constraints in the US economy.

In the model with binding leverage constraints, total leverage (investment relative to capital) is equal to1/ $(1-\kappa)$. The leverage ratio has a significant effect on the quantitative dynamics. We examine two alternatives. First we choose a relatively low ratio of $2(\kappa=0.5)$, as in Bernanke and Gertler (1999). But, given the high rates of leverage seen in the financial system in recent years, we also explore the implications of a higher value of $\kappa=0.75$, corresponding to total leverage of 4 . While the impact of shocks is greater for higher leverage (when the leverage constraint is binding), qualitatively the results are similar for both leverage ratios.

We assume a discount factor defined as:

$$
\beta^{i}(C)=\zeta^{i}(1+C)^{-\eta}, \quad i=I, S
$$

Following Mendoza (2006), we set $\eta=0.022$. We choose $\zeta$ for savers to match an annual interest rate of 4 percent, and the value of $\zeta$ for investors so that, in a steady state with binding leverage constraints, investors face a shadow price of borrowing that effectively imposes an interest premium on borrowed funds of two percentage points, which requires that $\zeta^{I}=0.955 .^{16}$ This follows the calibration of the borrowing premium in Bernanke et al. (1999).

In the model without leverage constraints, it is necessary to use a different approach to calibrate the discount factor. In that case, we choose $\zeta^{S}$ and $\zeta^{I}$ jointly to match a steady state annual interest rate of 4 percent and to ensure that borrowing by investors is such that the leverage ratio matches that of the economy with binding leverage constraints. In the

\footnotetext{
${ }^{16}$ From (6), this entails choosing $\beta^{I}$ so that $\mu$ / $\left[\beta^{I}\left(C^{I}\right) U^{\prime}\left(C^{I}\right)\right]$ is 0.02 in steady state.
} 
case $\kappa=0.75$, this requires that $\zeta^{S}=.99$ and $\zeta^{I}=.9735$. When $\kappa=0.5, \zeta^{S}=.9825$ and $\zeta^{I}=.975$

We assume a Cobb-Douglas final goods production technology, and let $F(L, K)=L^{1-\varepsilon} K^{\varepsilon}$. We set $\varepsilon=0.36$, the conventional measure of the share of capital in US GDP. ${ }^{17}$ Regarding the home production sector, we assume that $G=Z\left(k_{1}^{S}\right)^{\omega}$ and $\omega=0.1$, implying that the fixed asset is less important in this sector. ${ }^{18}$ We set $A=Z=1$ in steady state. The combination of these assumptions and other calibrated parameters implies that, in steady state, 80 percent of the fixed asset is employed in final goods production.

We follow the standard business cycle literature in setting an elasticity of intertemporal substitution equal to 0.5 , so that $\sigma=2$ in $U(C)=C^{1-\sigma} /(1-\sigma)$. Alternative values of $\sigma$ change the volatility of asset prices, but have little qualitative effect on the results otherwise.

What are the appropriate shocks to focus on? While the recent crisis has raised awareness of shocks to the financial system, our model lacks any detailed financial structure. It is not easy to pinpoint any key crisis-generating shock within the model. Instead, we follow the standard macro-RBC literature and look at the international propagation of productivity shocks in the final goods sector. The stochastic process for final goods productivity is modeled as:

$$
\log \left(A_{t}\right)=\rho \log \left(A_{t-1}\right)+v_{t}
$$

\footnotetext{
${ }^{17}$ In order to have substantial propagation effects from leverage constraints, Kiyotaki and Moore (1997) require that production in the borrowing sector is linear in the fixed asset. Kocherlakota (2000) shows that, with a more conventional calibration allowing for decreasing returns, credit constraints have much less impact. Cordoba and Ripoll (2004) extend the Kocherlakota analysis to a general equilibrium, two sector economy similar to ours. They show that borrowing constraints of the type used in Kiyotaki and Moore (1997) impart little amplitude to the effect of shocks on total output unless sectors differ substantially in the share of capital in production. Our interpretation differs from theirs by focusing on the distinction between the final goods sector and a home production sector. In addition, our main focus is not on amplification per se, but on the impact of leverage constraints and portfolio integration on the international transmission of shocks. Our results, showing that these two features enhance the international transmission of shocks, still obtain under the alternative interpretation that aggregate output is the sum of output from both sectors.

${ }^{18}$ Benhabib et al. (1991) calibrate the share of capital in home production equal to 0.08 .
} 
where $\rho=0.9, E_{t-1} v_{t}=0$ and $\sigma_{v}^{2}=0.02^{2}$. We assume that foreign productivity is driven by the same process, and foreign and domestic productivity shocks are uncorrelated.

\section{The effects of leverage constraints on international transmission}

In this section we compare the impact of a productivity shock in one country in an environment where leverage constraints are absent with that where investors in both countries are subject to binding leverage constraints. In both cases we assume that investors have diversified equity portfolios, potentially constrained only by second-order iceberg costs of capital flows, as described in (8'). The iceberg cost $\tau$ is set so as to ensure that domestic investors hold 75 percent of the home equity portfolio. We will also examine the case without these costs, so that investors have fully diversified equity portfolios. In addition, this section focuses on the case where national bond markets are segmented. Section 5 below analyzes the case with a single world bond market.

\section{No leverage constraints}

Figures 3 and 4 describe the impact of a one percent negative productivity shock in the home country, when the leverage constraint is not binding, relaxing (3). The figures describe the response of total consumption of final goods, ${ }^{19}$ asset prices, investor borrowing, asset allocation, the home country trade surplus and the internal lending rate in each country. Figure 3 represents the case where portfolio diversification is restricted by second-order transactions costs, as described above. Investors in the home country then choose values for $k_{1}^{I}$ and $k_{2}^{I}$ to satisfy (8'), evaluated up to second-order, where the parameter $\tau$ has been chosen so that home investors hold 75 percent of home equity $\left(k_{1}^{I}=.75 \hat{k}_{1}^{I}\right)$.

\footnotetext{
${ }^{19}$ We define total consumption of final goods as $n C_{t}^{I}+(1-n)\left(C_{t}^{S}-G\left(k_{t}^{I}\right)\right)$.
} 
Figure 3

No leverage constraints, partial diversification ${ }^{1}$
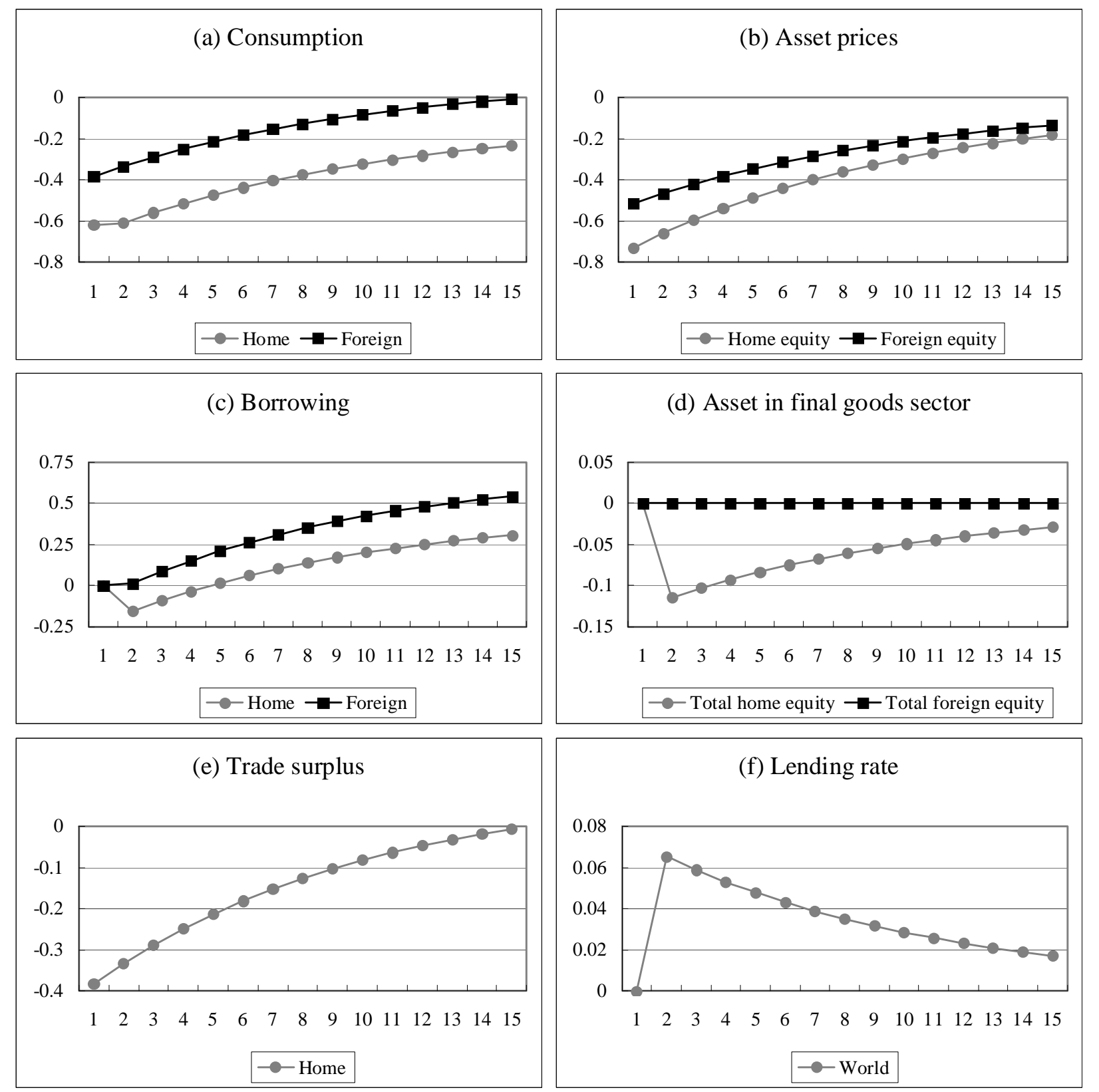

${ }^{1}$ Impulse responses of a one percent negative productivity shock when the leverage constraint is assumed to not bind (relaxing equation 3), and there is incomplete portfolio diversification $(\tau>0)$. 


\section{Figure 4}

\section{No leverage constraints, full diversification ${ }^{1}$}
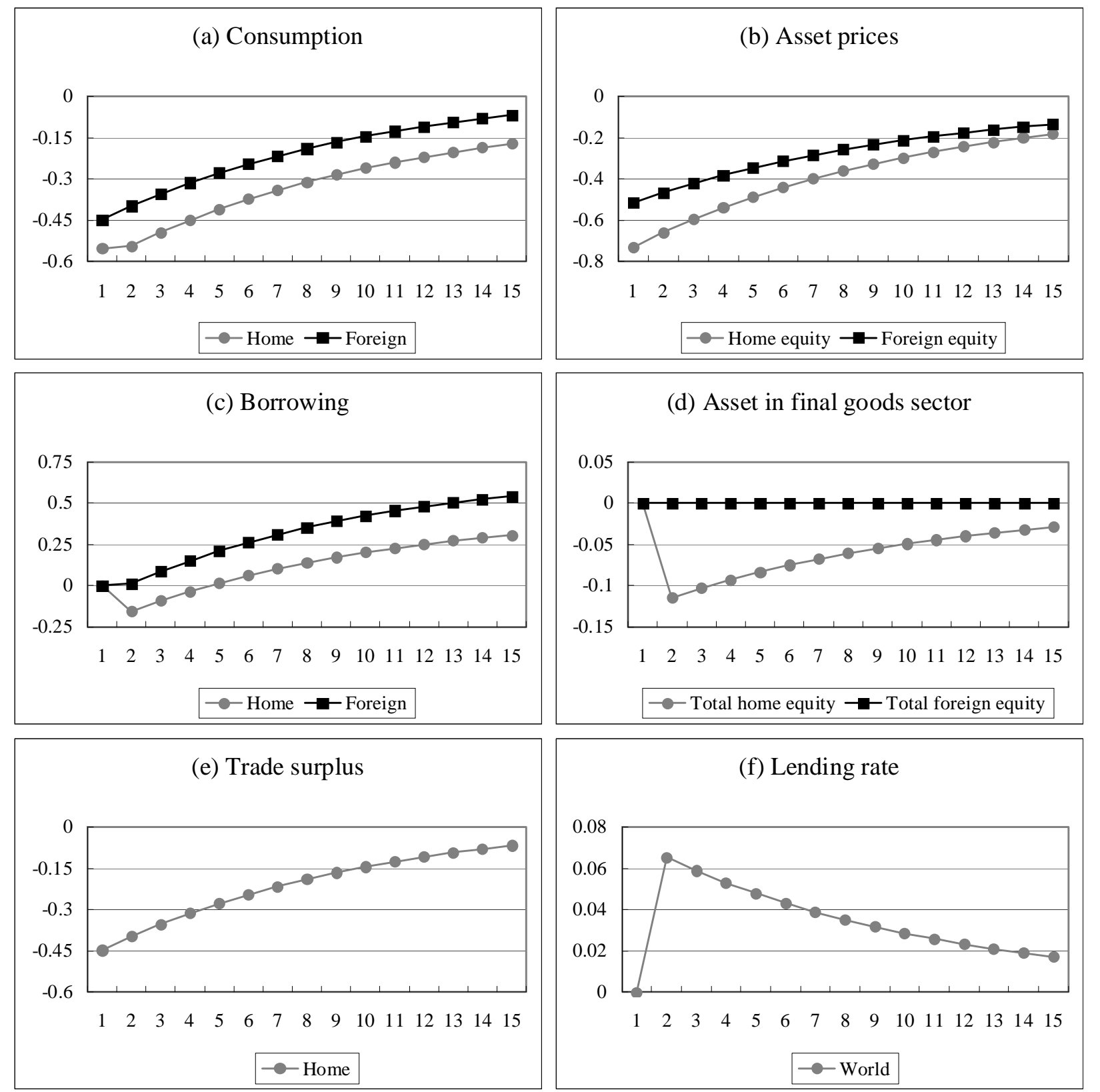

${ }^{1}$ Impulse responses of a one percent negative productivity shock when the leverage constraint is assumed to not bind (relaxing equation 3), and there is complete portfolio diversification $(\tau=0)$. 
Figure 4 describes the case of unrestricted portfolios. In this case, the choices of $k_{1}^{I}$ and $k_{2}^{I}$ satisfy (8). This involves home investors having a bias against home equities. Since investors are exposed to non-diversifiable risk from wage income, and wages are positively correlated with the return on home equity, they will hedge this risk by taking a larger position in foreign equity than home equity, as noted by Baxter and Jehrmann (1997).

A fall in $A_{t}$ causes an immediate fall in current output in the home country and temporarily reduces wages for both savers and investors. This would lead both savers and investors to increase their desired borrowing at the initial interest rates, so that net saving falls. If there was no cross-country equity trade, real interest rates would have to rise sufficiently so as to ensure that net saving equals zero. At the same time, the direct fall in the return on the fixed asset would lead investors to reduce their demand for this asset, leading to a reduction in withincountry borrowing of investors from savers, and precipitating a fall in the asset price. This fall in the asset price would lead savers to purchase more of the fixed asset. Thus, without international equity trade, adjustment would involve higher real interest rates, a lower asset price and a lower share of the fixed asset in the final goods sector, with all these variables gradually returning to their initial steady state.

In the two-country world economy with equity trade, the adjustment process is facilitated by the immediate valuation effects on home country net foreign assets, and the subsequent dynamics in net foreign assets due to changes in equity holdings. The international transmission of the shock to consumption depends on the degree of portfolio diversification, and the movement in asset returns. The home country has a negative net position in its own stock $\left(\alpha_{t}=q_{1 t-1}\left(k_{1 t-1}^{I}-\hat{k}_{1 t-1}^{I}\right)<0\right)$. Since asset returns must be equalized, up to a first order, the fall in asset prices in the home economy leads to a fall in the foreign asset price. But the ex-post excess 
return on home assets immediately following the shock is negative $\left(r_{x t}<0\right)$, and the combination of this and the home country's portfolio position ensures that the home country receives a positive portfolio valuation effect. In fact, with fully unrestricted diversification, foreign investors are more exposed to home equity, and suffer a bigger valuation loss on their portfolio, than home investors because home asset prices fall by more than foreign asset prices. Thus the home and foreign consumption responses in Figure 4 are more alike than in Figure 3, because there is more portfolio diversification among investors.

The subsequent adjustment in the two-country world economy is characterized by the home economy running a persistent trade deficit. This is financed by home country investors reducing their holdings of both home and foreign equities over time, and foreign country investors increasing their holdings of both equities. Since world real interest rates are higher following the shock, the foreign country as a whole increases its savings rate to absorb the greater holdings of equity.

The key feature of both Figures 3 and 4, however, is that there the shock does not affect the allocation of the fixed asset in the foreign country. ${ }^{20}$ Since the foreign asset allocation is governed by (20) up to a first order, optimal investment is unaffected by the shock to home productivity. This means that there is no fall in lending between foreign savers and foreign investors. In fact, within-country borrowing in the foreign country rises, moving in the opposite direction to that in the home country. ${ }^{21}$ In this sense, there is no international transmission of balance sheet contractions.

\footnotetext{
${ }^{20}$ Again, we note that in this and subsequent figures, the asset dynamics refer to total equity in each country (or equivalently, the shares of the fixed asset in the final goods sectors) $\hat{k}_{1, t}^{I}$ and $\hat{k}_{2, t}^{I}$, rather than the division of this equity between the portfolios of home and foreign investors.

${ }^{21}$ In fact, since foreign lenders do not interact with home agents, foreign investors are effectively borrowing from foreign lenders in order to purchase more home and foreign equity during the transition. In the home country, the
} 
In the economy without leverage constraints, then, the international transmission of shocks is limited, and clearly counterfactual, relative to the discussion of the empirical evidence of financial spillovers in section 2. A negative productivity shock in the home country leads to balance sheet contractions domestically as investors reduce both their borrowing and holdings of fixed assets. But there are no foreign balance sheet contractions. Equity portfolio integration allows for the consumption effects of productivity shocks to be diversified across countries, but it does not in itself influence the real effects of the shock on investment and output. ${ }^{22}$

\section{Leverage constraints and international transmission}

The impact of a negative productivity shock in the home country, when leverage constraints bind in both countries, is shown in Figures 5-7. Figures 5 and 6 illustrate the case where the leverage ratio is 4 , the former when investors' portfolios are only partly diversified due to the presence of transactions costs and the latter with unrestricted portfolio diversification.

As before, the fall in home country productivity leads to a fall in asset prices in both countries and, through the valuation effects of ex-post asset return differentials between the home and foreign portfolios, to an increase in net foreign assets for the home country, and a fall in investors' consumption in both countries. But in this environment asset prices have a secondary effect, beyond the wealth redistribution channel, through the return on portfolios. The fall in asset prices leads to a tightening of the leverage constraint in both the home and foreign countries. For the home country, the fall in $q_{1 t}$ leads to a fall in net worth and, for given NFA, requires a reduction in borrowing. With a diversified portfolio, however, the shock also generates a valuation effect, causing a compensating rise in NFA. But this leads to negative movement in

dynamic is the opposite - home investors reduce their borrowing from home savers (at least initially), financed by sales of equity to foreign investors.

${ }^{22}$ Again, we note that, with endogenous labour supply and capital accumulation, the degree of portfolio diversification would impact on the international transmission of shocks, but this would generally imply negative transmission. 
foreign $N F A$, and a tightening of the foreign leverage constraint, also requiring a reduction in borrowing in the foreign country. The result is a reduction in borrowing by investors in both countries, and a consequent reduction in investment in fixed assets in the final goods sector. Thus Figure 5 illustrates that foreign investment falls sharply, by the same order of magnitude as home investment. Note that, for the foreign country, there is no fall in the productivity of the domestic final goods sector. Despite that, there is a fall in investment in final goods in the foreign country. This fall in investment takes place purely through balance sheet linkages.

The positive relationship between the movement in an asset price and demand for this asset represents the essence of the 'upward sloping demand curve' for assets that characterizes episodes of balance sheet contractions forced by binding leverage constraints (see, for instance, Aiyagari and Gertler 1999). Here it is taking place as a spillover from one levered investor to another, as emphasized by Krugman (2008). That is, a fall in the price of the asset held by one investor leads to a tightening of leverage constraints and a fall in demand for both the original asset and other assets held in the investor's portfolio.

Even in the case where portfolios are only partly diversified (Figure 5), there is a high correlation across countries in borrowing and investment. The balance sheet contraction is so great that the interest rate on debt in each country immediately falls. Again, note that this is in response to a temporary shock so that future consumption of investors is expected to increase. But because investors are subject to leverage constraints, the path of their consumption is delinked from the path of interest rates. 
Figure 5

High leverage constraints, partial diversification ${ }^{1}$
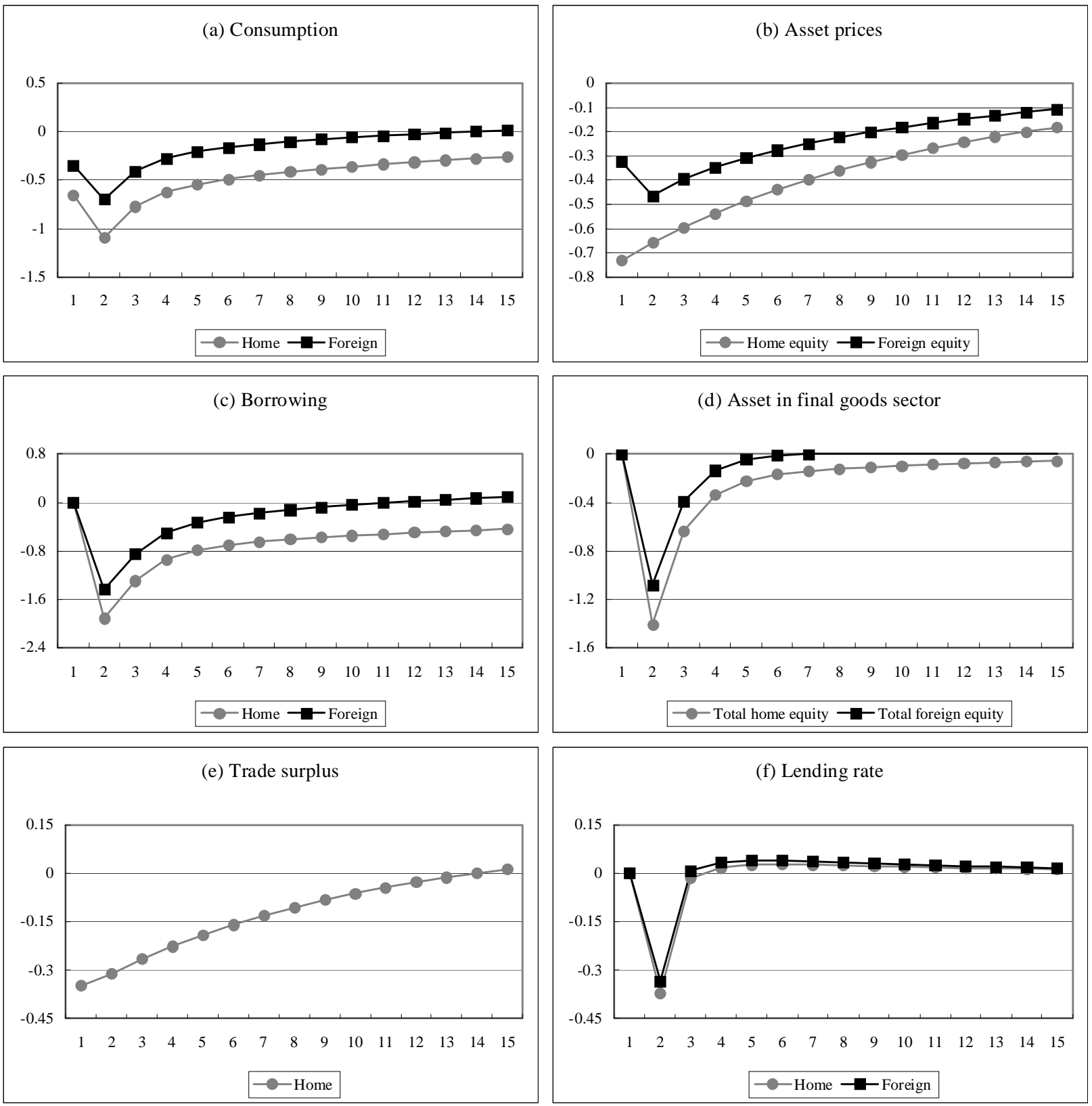

${ }^{1}$ Impulse responses of a one percent negative productivity shock with a high, binding leverage constraint $(\kappa=0.75)$ and incomplete portfolio diversification $(\tau>0)$. 


\section{Figure 6}

\section{High leverage constraints, full diversification ${ }^{1}$}
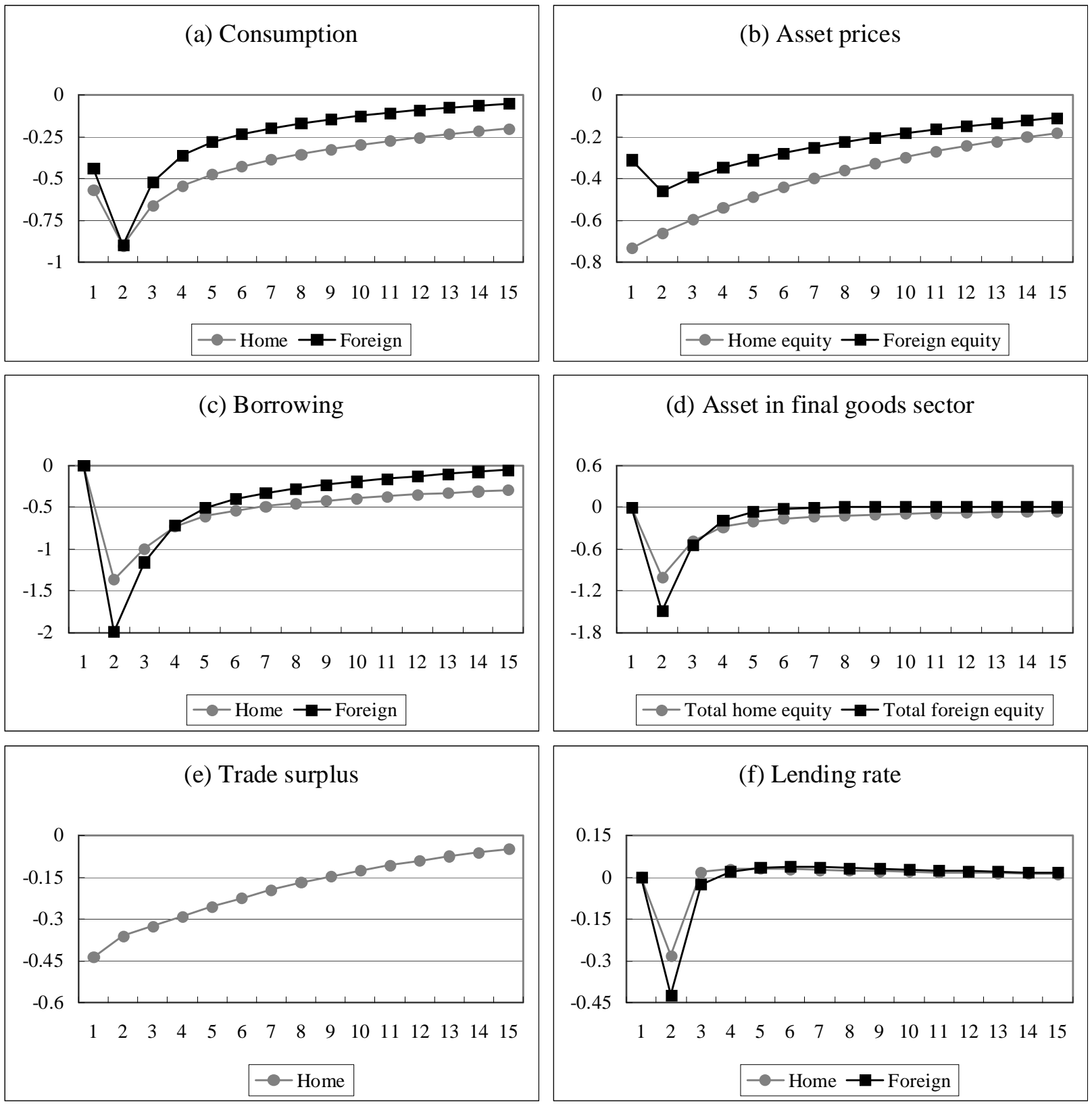

${ }^{1}$ Impulse responses of a one percent negative productivity shock with a high, binding leverage constraint $(\kappa=0.75)$ and complete portfolio diversification $(\tau=0)$. 
Since consumption falls for both home and foreign investors, but is expected to rise in the future, real interest rates would tend to rise in an unrestricted environment. ${ }^{23}$ But this effect is more than offset by the increase in the shadow price of borrowing due to the leverage constraint. This leads to a large fall in the supply of debt to savers, and a fall in market real interest rates.

There is a distinct difference in this model between the constrained and unconstrained economy, not just in the direction of the international transmission of shocks, but also in the scale of the effects. In the unconstrained economy, not only is there an absence of international transmission via balance sheet contractions, but the domestic impact of the shock is also relatively mild. A one percent decline in final goods' sector productivity leads only to an approximately 0.25 percent reduction in fixed asset investment. By contrast, the response of the constrained economy is an order of magnitude larger. Domestic investment in fixed assets falls by 1.7 percent. Even in the foreign economy the effect of the shock is very large - investment falls by 1.3 percent. In both countries, the response to the shock is proportionally much larger than the shock itself, due to the interaction between asset price declines and binding leverage constraints. Consumption also falls by slightly more in the constrained economy than in the unconstrained economy, although this decline is less persistent.

When portfolio diversification is unrestricted, Figure 6 shows that the international transmission of the shocks is heightened further. In fact, we get the surprising prediction that the size of the balance sheet contraction and disinvestment is greater in the foreign country than in the home country! Investment in the foreign economy falls by 1.6 percent, but only 1.2 percent in the domestic economy.

\footnotetext{
${ }^{23}$ There is not a strict relationship between expected consumption growth and real interest rates, up to a first-order, due to the presence of endogenous time preference. Nevertheless, since the time preference parameter $\eta$ is very small, for practical purposes the consumption growth-real interest rate linkage holds quite closely in the model. Note also that, because interest rate movements are non-monotonic, the same will (approximately) hold for the nonborrowing constrained savers in each country.
} 
Why does greater portfolio diversification magnify the international propagation effects of the shock? The reason is clear from (3) or (23). Increased diversification leads to a greater sensitivity of foreign balance sheets to the domestic asset price, and therefore a larger balance sheet contraction in response to a negative shock to home productivity. In the completely unrestricted portfolio equilibrium (when $\tau=0$ ), the foreign country is over-weighted in home equity as part of an optimal risk sharing arrangement. So the macroeconomic reverberations of the shock are greater in the foreign country than the domestic country, despite the fact that the actual shock takes place only in the home economy. Thus, in this example, the ownership pattern of equity holdings, through its implication for balance sheet constraints, is more important for the business cycle response than is the geographical source of macro shocks.

Figure 7 shows the results with a lower degree of leverage (equal to 2), when portfolio diversification is restricted by transactions costs (the case of full diversification is very similar and is omitted for brevity). Qualitatively the results are very similar, although the amplification effect of shocks is lower when leverage is smaller. The presence of binding leverage constraints still generates a high positive co-movement in borrowing and real investment between countries. 
Figure 7

\section{Low leverage constraints, partial diversification ${ }^{1}$}
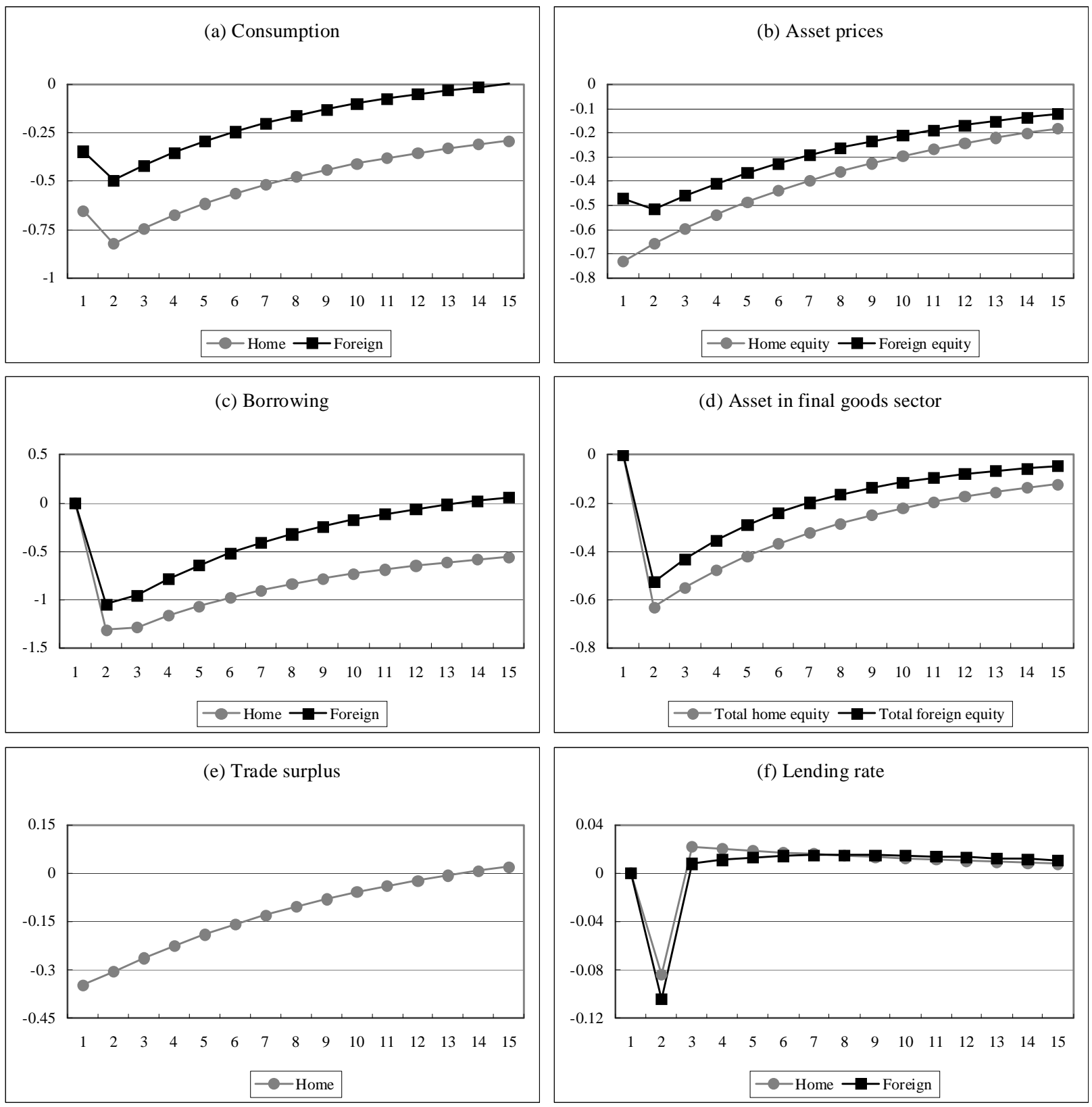

${ }^{1}$ Impulse responses of a one percent negative productivity shock with a low, binding leverage constraint $(\kappa=0.5)$ and incomplete portfolio diversification ( $\tau>0)$. 


\section{Portfolio Integration and international transmission}

In this section we examine the version of the model that allows for an integrated world market for non-contingent bonds. Now investors may borrow at the same interest rate from either domestic or foreign savers. We use this version to explore the impact of equity market integration in the presence of leverage constraints. That is, in contrast to the previous section where we compared the effects of a productivity shock assuming integrated equity markets (to a greater or lesser degree, depending on the value of $\tau$ ), both with and without leverage constraints, here we assume that leverage constraints are always binding, but we contrast the case with and without equity market integration. ${ }^{24}$

Figure 8 illustrates the impact of a shock to productivity in the home country in the model with a common bond market, but without equity market integration. In this environment, the transmission of macroeconomic shocks across countries is negative $!^{25}$

\footnotetext{
${ }^{24}$ This was not possible in the previous section because, absent equity market integration, the two countries were effectively in autarky, since bond markets were segmented by country. We note also that Dedola and Lombardo (2009) look at various degrees of portfolio integration.

${ }^{25}$ We focus only on the high leverage case here. The impact of portfolio integration in the case with lower leverage is qualitatively similar, in the sense that portfolio integration increases macroeconomic co-movement when compared with the economy without equity market integration. However, in the economy without integration and lower leverage (the counterpart of Figure 8), the co-movement is likely to be positive rather than negative since a negative productivity shock will tend to raise rather than lower world lending rates with low leverage. Thus the case of negative co-movement depends on both the absence of portfolio integration and high levels of leverage. Nevertheless, the main result that follows - that equity market integration increases macroeconomic co-movement remains even with low leverage.
} 


\section{Figure 8}

\section{Integrated bond markets, segregated equity markets ${ }^{1}$}
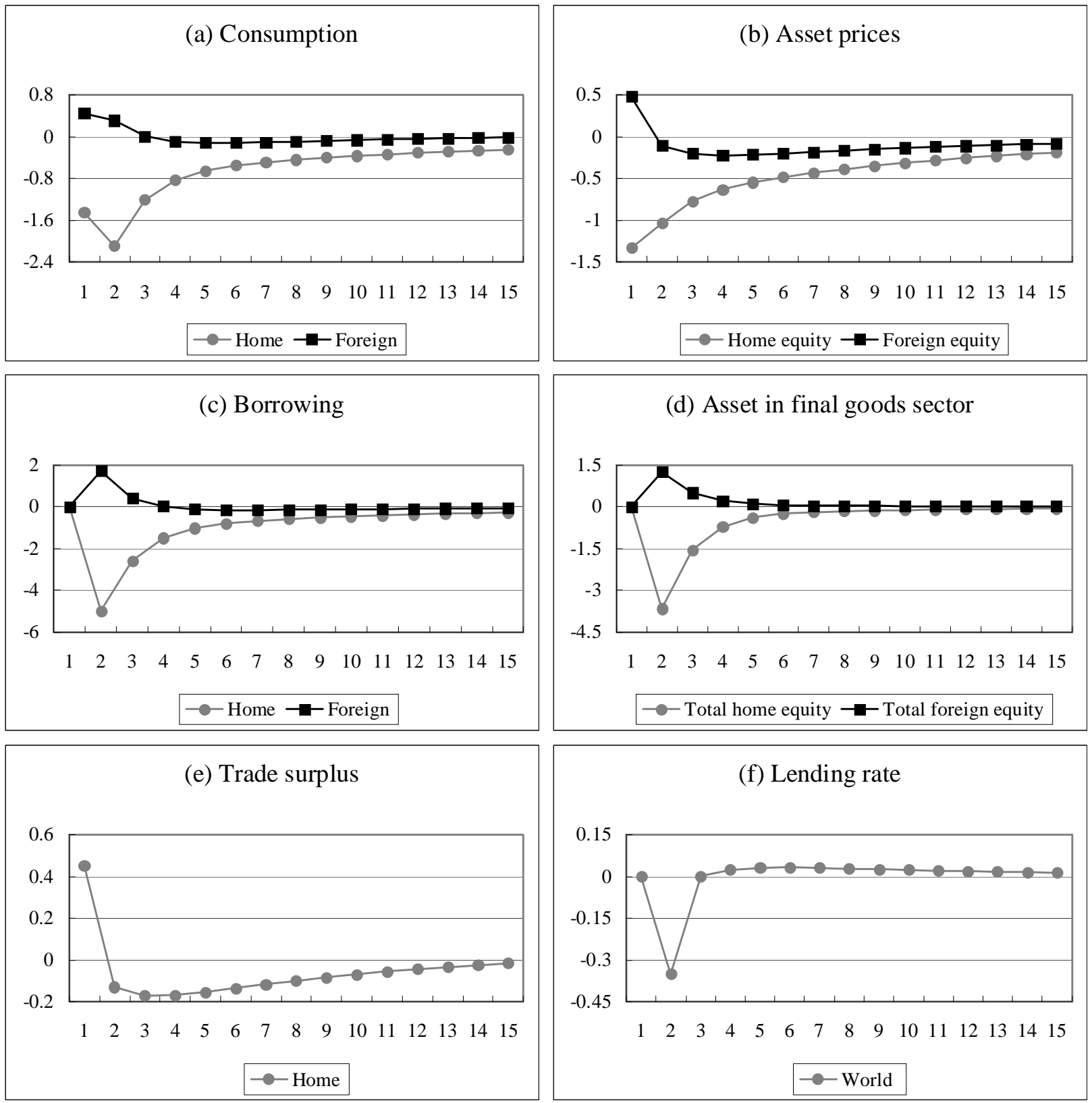

${ }^{1}$ Impulse responses of a one percent negative productivity shock with a high, binding leverage constraint ( $\kappa=0.75$ ), integrated bond markets $\left(R_{t}=R_{t}^{*}\right)$ and segmented equity markets. 
As before, a decline in home country productivity reduces investment, borrowing and aggregate consumption in the home economy. But because the borrowing rate is identical in both countries, and the fall in the demand for funds on the part of home investors pushes down the borrowing rate, the demand for funds in the foreign country rises, increasing borrowing and investment in the fixed asset by foreign investors. Foreign total consumption rises, as the fall in interest rates encourages an increase in spending, and the rise in foreign investment increases production of final goods in the foreign country. In contrast to the case without an integrated world bond market, the home country's trade balance now moves into surplus, rather than deficit.

The different responses of home and foreign investment lead asset prices to move in opposite directions in the two countries. There is an asset price decline in the home country, for the same reasons as before. In the foreign country, by contrast, the increase in demand for the fixed asset raises the price of that asset. Thus the end result is that consumption, investment, and asset prices move in opposite directions in the two countries when there is an integrated world bond market but no equity market integration. Notice also that the amplification effects of the shock on domestic investment and asset prices are substantially bigger in this case than in Figures 5 or 6 . Because equity prices across countries are not directly related through arbitrage, home country asset prices fall by more, and the impact on the leverage constraint is amplified, relative to the case with equity market integration.

Figure 9 now takes the same shock, but allows for both bond and equity market integration, assuming unrestricted equity holdings (the case with iceberg costs on equity returns is very similar, and is omitted for brevity). In this case there is a clear positive co-movement across countries. Qualitatively, the transmission is similar to Figures 5 and 6, except now there is 
a single world debt market. The shock leads to a fall in the price of the home asset and, from arbitrage condition (8), the foreign asset price also falls. Given the hedged portfolio position of the home country, the fall in the return on the home asset leads to an increase in home NFA due to valuation effects. For the foreign country these valuation effects are negative, leading to a tightening of the leverage constraint on foreign investors. As in Figures 5 and 6, total borrowing, investment and consumption fall in both countries. The world real interest rate on debt also falls, as the demand for borrowing by both home and foreign investors declines.

A comparison between Figures 8 and 9 illustrates that, conditional on leverage constrained investment, portfolio integration itself causes a dramatic qualitative shift in the international transmission of productivity shocks. Absent equity market integration, shocks are transmitted negatively to consumption, asset prices and investment. There would thus be a clear incentive to diversify country specific risk through equity market integration. But integrating equity markets in the presence of binding leverage constraints causes a sharp change in the nature of international transmission itself. Without leverage constraints, as we have seen, there would be no such effects. Real investment would be entirely independent across countries in this basic model, and opening up financial markets in equity trade would have no effect on comovement whatsoever, aside from the direct effect on consumption risk-sharing. But with binding leverage constraints, portfolio diversification leads to large shifts in net worth across countries in response to country-specific shocks. These net worth changes interact with leverage constraints to cause highly synchronized movements in investment demand across countries. Thus, the ex-post gains to diversification, after financial integration, are diminished relative to ex-ante 'perceived' gains from equity market integration. 


\section{Figure 9}

\section{Integrated bond and equity markets ${ }^{1}$}
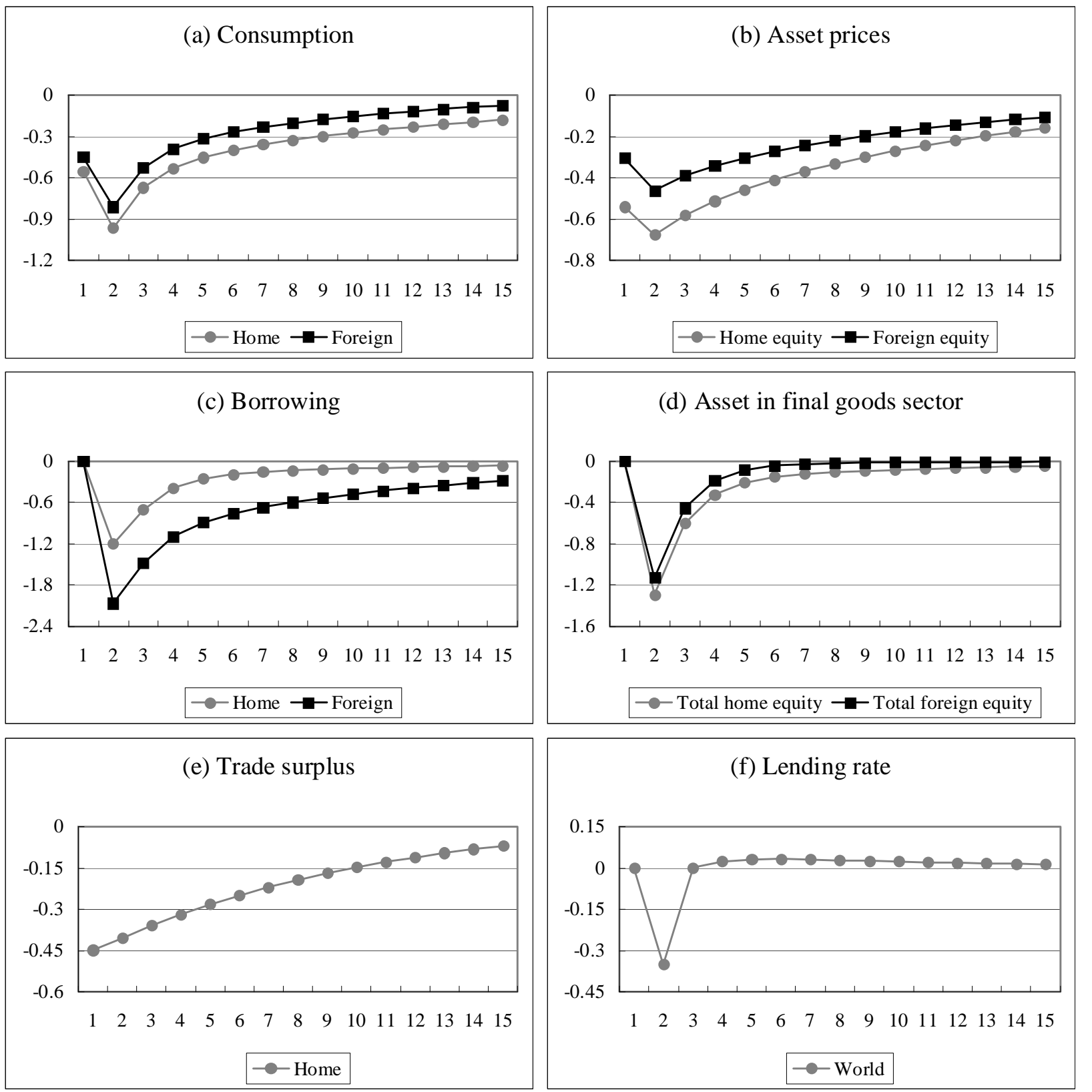

${ }^{1}$ Impulse responses of a one percent negative productivity shock with a high, binding leverage constraint ( $\kappa=0.75$ ), integrated bond markets $\left(R_{t}=R_{t}^{*}\right)$ and integrated equity markets with complete portfolio diversification $(\tau=0)$. 
Equivalently we can observe that, while financial integration through equity markets allows for a positive gain from cross country risk-sharing, it also generates a 'contagion' effect in the presence of leverage constraints on investment. This contagion effect works through crosscountry changes in net worth, affecting investment and increasing the degree of macroeconomic co-movement relative to that which would obtain in the absence of portfolio integration.

\section{Unconditional moments}

Table 4 reports the unconditional moments of the model under the assumption that productivity shocks in both countries follow identical but uncorrelated distributions, given by (24). As is evident from the figures, the model with binding leverage constraints displays substantially more overall volatility than the model where leverage constraints are absent. Aggregate consumption is 50 percent more volatile with high leverage constraints. Asset price volatility is relatively unchanged with and without leverage constraints, but investment volatility is vastly higher, as is clear from a comparison of Figures 3 and 5. Investment is essentially uncorrelated across countries in the economy without leverage constraints, but almost perfectly correlated in the economy with leverage constraints. Table 4 therefore underscores the main message of the paper. In the presence of credit market imperfections, balance sheet linkages across financial institutions can generate a very powerful mechanism for the international transmission of business cycle shocks. The table also shows that, in the presence of leverage constraints, international portfolio diversification can lead to a dramatic change in macroeconomic co-movement. The cross-country correlations of consumption, asset prices and investment switch from negative to positive when equity markets are opened and leverage constraints are binding. Note, however, that overall macro volatility is still substantially reduced by financial integration, as suggested by Figure 9 . 


\begin{tabular}{|c|c|c|c|c|c|c|c|c|}
\hline & & Uncondi & $\begin{array}{l}\text { Table } 4 \\
\text { tional } n\end{array}$ & oment & & & & \\
\hline $\begin{array}{l}\text { International } \\
\text { Bond Markets }\end{array}$ & & & Segmei & & & & Uni & ied \\
\hline $\begin{array}{l}\text { Leverage } \\
\text { constraints }\end{array}$ & $\begin{array}{c}\text { Not } \\
\text { binding }\end{array}$ & $\begin{array}{c}\text { Not } \\
\text { binding }\end{array}$ & High & High & Low & Low & High & High \\
\hline $\begin{array}{l}\text { International equity } \\
\text { diversification }\end{array}$ & Partial & Full & Partial & Full & Partial & Full & None & Full \\
\hline $\begin{array}{l}\text { Corresponding } \\
\text { figure }\end{array}$ & 3 & 4 & 5 & 6 & 7 & - & 8 & 9 \\
\hline $\operatorname{SDEV}(C)$ & 1.9 & 1.9 & 2.8 & 2.7 & 2.4 & 2.4 & 4.7 & 2.8 \\
\hline $\operatorname{SDEV}\left(q_{1}\right)$ & 2.2 & 2.3 & 2.1 & 2.0 & 2.4 & 2.5 & 3.2 & 2.2 \\
\hline $\operatorname{SDEV}(R)$ & 0.2 & 0.2 & 1.0 & 1.0 & 0.3 & 0.3 & 1.0 & 1.0 \\
\hline $\operatorname{SDEV}\left(\hat{k}_{1}^{I}\right)$ & 0.3 & 0.3 & 3.5 & 3.5 & 2.0 & 2.1 & 7.7 & 3.4 \\
\hline $\operatorname{CORR}\left(C, C^{*}\right)$ & 0.87 & 0.96 & 0.89 & 0.97 & 0.86 & 0.98 & -0.37 & 0.98 \\
\hline $\operatorname{CORR}\left(q_{1}, q_{2}\right)$ & 0.94 & 0.94 & 0.93 & 0.91 & 0.92 & 0.91 & -0.26 & 0.92 \\
\hline $\operatorname{CORR}\left(\hat{k}_{1}^{I}, \hat{k}_{2}^{I}\right)$ & -0.03 & 0.01 & 0.96 & 0.90 & 0.96 & 0.92 & -0.63 & 0.98 \\
\hline $\operatorname{CORR}\left(R, R^{*}\right)$ & 1.00 & 1.00 & 0.99 & 0.92 & 0.97 & 0.63 & 1.00 & 1.00 \\
\hline \multicolumn{9}{|c|}{$\begin{array}{l}{ }^{1} \text { Unconditional moments if productivity shocks follow identical but uncorrelated distributions in } \\
\text { both countries, with varying degrees of market integration and levels of leverage. High (low) } \\
\text { leverage constraints corresponds to } \kappa=0.75(0.5) \text {. Partial and full international equity } \\
\text { diversification correspond to } \tau>0 \text { and } \tau=0 \text { respectively. } C\left(C^{*}\right) \text { is domestic (foreign) } \\
\text { consumption; } q_{1}\left(q_{2}\right) \text { is domestic (foreign) equity prices; } R\left(R^{*}\right) \text { is domestic (foreign) interest } \\
\text { rates and } \hat{k}_{1}^{I}\left(\hat{k}_{2}^{I}\right) \text { is the quantity of domestic (foreign) fixed assets used in final goods production. }\end{array}$} \\
\hline
\end{tabular}

\section{Extending the model: endogenous capital accumulation and labor supply}

The paper has stressed the joint effects of leverage constraints and international portfolio integration in generating positive international co-movement in macro aggregates. The key mechanisms are based on interdependence in balance sheets and the magnification effects of asset price shocks in face of leverage constraints. The model lacks many of the standard features 
of the international real business cycle (IRBC) literature, however. In particular, labor supply of both investors and savers is assumed to be inelastic, and there is no endogenous physical capital accumulation. A natural question to ask is whether the forces for positive macro co-movement outlined in the basic model extend to a full IRBC environment. In an interesting recent paper, Faia (2007) provides some relevant results. She explores the role of financial integration in DSGE framework where financial frictions in the manner of Bernanke et al. (2000) are present. Her results show that these financial frictions lead to a greater synchronization of international business cycles.

Exploring the full implications of the leverage constraints and portfolio diversification channels for international business cycles is beyond the scope of the present paper. However, Devereux Sutherland and Yetman (2010) extend the basic model to a richer international business cycle environment, incorporating endogenous labor supply, reproducible capital accumulation and quadratic adjustment costs of investment, in conjunction with the channels of portfolio diversification and leverage constraints described above. Under this extension, the general features of the results described above continue to hold. In particular, the presence of leverage constraints generates an 'international finance multiplier’ which tends to reverse the sign of the international macro-transmission of shocks. Nevertheless, a large number of questions remain unanswered - in particular pertaining to the role of financial shocks relative to real shocks, the comparison of different types of financial frictions and the role for financial intermediaries in the international propogation of shocks.

In some ways investors in our model may be thought to parallel the banking system. In the model investors borrow money from savers and use this to invest in fixed assets, which might be thought of as similar to the way in which the banking system intermediates between deposits 
and loans. Also, the downturn in our model, amplified by leverage constraints, might be seen as similar to the debt deflation and balance sheet deterioration within the banking system which operated during the financial crisis. However, the analogy to financial institutions is not perfect. For example, there is no maturity transformation in our model, which is a distinguishing feature of the banking system. In addition, whereas it is generally assumed that banks lend to entrepreneurs who then undertake investment projects, here the investors themselves take equity stakes in the capital projects.

\section{Conclusions}

This paper has provided empirical evidence on the importance of balance sheet adjustments in propagating business cycle shocks across countries. Financial interdependence, combined with financial vulnerabilities, can open a channel for the transmission of shocks that may be as important as standard trade linkages. We have used this evidence to motivate a simple twocountry model in which highly levered financial institutions hold inter-connected portfolios, and may be limited in their investment activity by capital constraints. The combination of portfolio inter-dependence and capital constraints leads a negative shock in one country to precipitate an episode of global balance sheet contractions and disinvestment. In this sense our model may be

seen as a formal general equilibrium representation of Krugman (2008) who suggests that interconnections in financial markets may give rise to an 'international finance multiplier.' In our model we find that, with high initial levels of leverage, the global effects of the shock may be substantially magnified. While the model illustrates the importance of financial connections, it abstracts away from trade inter-linkages. In a more elaborate model, it would be desirable to quantitatively investigate the relative importance of the two separate channels. 


\section{References}

Aghion, Philippe, Philippe Bacchetta and Abhijit Banerjee (2004). "Financial development and the instability of open economies,” Journal of Monetary Economics, 51(6), 1077-1106.

Aiyagari, S. Rao and Mark Gertler (1999). “'Overreaction” of asset prices in general equilibrium,” Review of Economic Dynamics, 2(1), 3-35.

Backus, David K., Patrick J. Kehoe and Finn E. Kydland (1992). "International real business cycles,” Journal of Political Economy 100(4), 745-775.

Baxter, Marianne and Mario J. Crucini (1995). "Business cycles and the asset structure of foreign trade,” International Economic Review 36(4), 821-854.

Baxter, Marianne and Urban J. Jermann (1997). "The international diversification puzzle is worse than you think,” American Economic Review 87(1), 170-180.

Benhabib, Jess, Richard Rogerson and Randall Wright (1991). "Homework in macroeconomics: household production and aggregate fluctuations,” Journal of Political Economy 99(6), 1166-1187.

Bernanke, Ben S., Mark Gertler and Simon Gilchrist (1999). “The financial accelerator in a quantitative business cycle framework.” In John B. Taylor and Michael Woodford (eds.), Handbook of Macroeconomics Volume 1C, 1341-1393, North-Holland.

Bernanke, Ben S., and Mark Gertler (1999). "Monetary policy and asset price volatility,” Federal Reserve Bank of Kansas City Economic Review, Fourth Quarter, 17-51.

Campbell, John Y. and N. Gregory Mankiw (1990). "Permanent income, current income, and consumption,” Journal of Business and Economic Statistics, 8(3), 265-279.

Cordoba, Juan-Carlos and Marla Ripoll (2004). “Credit cycles redux,” International Economic Review 45(4), 1011-1046.

Dedola, Luca and Giovanni Lombardo (2009). "Financial frictions, financial integration and the international propagation of shocks,” mimeo.

Devereux, Michael B. and Alan Sutherland (2010a). "Country portfolios in open economy macro models," Journal of the European Economic Association, forthcoming.

Devereux, Michael B. and Alan Sutherland (2010b). “Country portfolio dynamics,” Journal of Economic Dynamics and Control, forthcoming.

Devereux, Michael B. and James Yetman (2010). “An international business cycle model of financial transmission,” in progress.

Faia, Ester (2007). “Finance and international business cycles,” Journal of Monetary Economics 54(4), 1018-1034.

Geanakoplos, John (2009). “The leverage cycle,” NBER Macroeconomics Annual, forthcoming.

Gilchrist, Simon (2004). "Financial markets and financial leverage in a two-country world economy,” In Luis Antonio Ahumada and J. Rodrigo Fuentes (eds.), Series on Central Banking, Analysis and Economic Policies, Vol VII: Banking Market Structure and Monetary Policy, Central Bank of Chile 
Heathcote, Jonathan and Fabrizio Perri (2005). "Financial globalization and real regionalization,” Journal of Economic Theory, 119(1), 207-243.

Heathcote, Jonathan and Fabrizio Perri (2002). "Financial autarky and international business cycles,” Journal of Monetary Economics, 49(3), 601-627.

Iacoviello, Matteo (2005). "House prices, borrowing constraints, and monetary policy in the business cycle,” American Economic Review, 95(3), 739-764.

Imbs, Jean (2004). “Trade, finance, specialization, and synchronization,” Review of Economics and Statistics, 86(3), 723-734.

Imbs, Jean (2006). “The real effects of financial integration,” Journal of International Economics, 68(2), 296-324.

Kiyotaki, Nobuhiro and John Moore (1997). “Credit cycles,” Journal of Political Economy, 105(2), 211-248.

Kocherlakota, Narayana R. (2000). "Creating business cycles through credit constraints,” Federal Reserve Bank of Minneapolis Quarterly Review, 24(3), 2-10.

Kose, M. Ayhan, and Kei-Mu Yi (2006). “Can the standard international business cycle model explain the relation between trade and comovement?” Journal of International Economics, 68(2), 267-295.

Krugman, Paul (2008). “The international finance multiplier,” http://www.princeton.edu/ pkrugman/finmult.pdf.

Mendoza, Enrique G. and Katherine A. Smith (2006). "Quantitative implications of a debtdeflation theory of Sudden Stops and asset prices," Journal of International Economics, 70(1), 82-114.

Mendoza, Enrique G. (2006). "Endogenous sudden stops in a business cycle model with collateral constraints: a Fisherian deflation of Tobin's Q,” NBER Working Paper, 12564.

Mohan, Rakesh (2009). “Global financial crisis: causes, consequences and India's prospects,” http://rbidocs.rbi.org.in/rdocs/Speeches/PDFs/IIBISSApril212009.pdf.

Pavlova, Anna and Roberto Rigobon (2008). "The role of portfolio constraints in the international propagation of shocks,” Review of Economic Studies, 75(4), 1215-1256.

Rigobon, Roberto (2003). "On the measurement of the international propagation of shocks: is the transmission stable?” Journal of International Economics, 61(2), 261-283.

Tille, Cedric and Eric van Wincoop (2007). “International capital flows,” Federal Reserve Bank of New York Staff Report, 280.

Uribe, Martin (2006). "Individual versus aggregate collateral constraints and the overborrowing syndrome,” NBER Working Paper, W12260. 